\title{
Assessment of a spodumene ore by advanced analytical and mass spectrometry techniques to determine its amenability to processing for the extraction of lithium
}

\author{
Mark G. Aylmore ${ }^{1}$, Kelly Merigot ${ }^{1}$, William D.A. Rickard ${ }^{1,2}$, Noreen J. Evans ${ }^{1,2,3}$, Bradley J. McDonald ${ }^{1,3}$, Enej \\ Catovic $^{4}$, Peter Spitalny ${ }^{4}$ \\ ${ }^{1}$ John de Laeter Centre, Faculty of Science \& Engineering, Curtin University \\ ${ }^{2}$ The Institute for Geoscience Research, Curtin University \\ ${ }^{3}$ Department of Applied Geology, Curtin University, \\ ${ }^{4}$ Lithium Australia
}

Corresponding Author

\author{
Mark Aylmore \\ mark.aylmore@curtin.edu.au
}

\begin{abstract}
A combination of analytical microscopy and mass spectrometry techniques have been used to detect and characterise different lithium minerals in a LCT-Complex spodumene-type pegmatite from Pilgangoora located in the Pilbara region of Western Australia. Information collated by these techniques can be used to predict processing amenability. Samples were categorised into three subsamples (Pil1, Pil2, Pil3) based on colour and texture having different lithologies.
\end{abstract}

The mineralogy and liberation characteristics of samples were characterised using automated mineralogy techniques and the Li content and elemental distribution within minerals defined using instrumentation with secondary mass spectrometry capabilities. The majority of lithium is associated with spodumene particles with minor amounts of lithium bearing micas and beryl in the Pill sample, whereas in Pil2 and Pil3 spodumene is largely the lithium source. In the Pill sample a proportion of spodumene particles have undergone alteration with spodumene being replaced by micaceous minerals of muscovite, lepidolite and trilithionite, as well as calcite. In Pil2 and Pil3 samples the spodumene particles are generally free of mineral impurities except minor intergrowths of quartz, feldspar and spodumene are evident in the coarser fractions.

Based on mineralogical observations in the current study, the majority of the main gangue minerals quartz, $\mathrm{K}$ feldspar and albite can be rejected at a coarse grind size of $-4 \mathrm{~mm}$, to recover $90 \%$ of the spodumene with $\mathrm{Li}$ upgrade from $0.99-1.5 \mathrm{wt} \% \mathrm{Li}$ to $3.0-3.5 \mathrm{wt} \%\left(6.5-7.5 \mathrm{Li}_{2} \mathrm{O}\right)$. The iron content (81-1475ppm) in the spodumene is low and therefore make these spodumene concentrates suitable for use in ceramic and glass applications.

Recovery of spodumene in the coarse fractions could be improved by further particle size reduction to liberate spodumene from micas and feldspars in the middling class, which account for between 15 and $49 \%$ of the sample. However, the requirement to remove mineral impurities in the spodumene in downstream processing will be dependent on the method of processing as the presence of Li bearing micas, calcite and feldspar can be beneficial or detrimental to lithium recovery.

The high content of $\mathrm{Rb}(1 \mathrm{wt} \%)$ and the abundance of free grains makes $\mathrm{K}$ feldspar a source of rubidium, particularly in the Pil3 sample which has K feldspar in high abundance (21 wt\%) and can potentially be recovered by reverse flotation technique.

The low concentrations of the $\mathrm{Ta}, \mathrm{Nb}$ and $\mathrm{Sn}$ minerals identified in samples were found to be fairly well liberated and could be recovered by conventional gravity separation techniques. 


\section{Introduction}

The demand for lithium has increased significantly in recent years as a result of an increase in demand for lithium based rechargeable batteries for portable electronic devices (e.g. mobile phones, computers and rechargeable power tools) and electric passenger cars. Spodumene $\left(6.0-7.5 \% \mathrm{Li}_{2} \mathrm{O}\right)$ in high grade lithium-caesium-tantalum (LCT) pegmatite deposits is a major source of lithium. Other lithium minerals which are considered of commercial value are petalite $\left(3.5-4.5 \% \mathrm{Li}_{2} \mathrm{O}\right)$, and the $\mathrm{Li}$-bearing micas (polylithionite, trilithionite, lepidolite, zinnwaldite, which contain $\mathrm{Li}_{2} \mathrm{O}$ ranging from 2.0 to $7.7 \%)$. Spodumene occurs naturally in the $\alpha$ monoclinic $(\mathrm{C} 2 / \mathrm{c})$ form as a member of the pyroxene group and found associated with quartz, albite, microcline and micas in pegmatite deposits. Pure stoichiometric chemical composition of spodumene consists of 8.0 wt. $\% \mathrm{Li}_{2} \mathrm{O}, 27.4$ wt. $\% \mathrm{Al}_{2} \mathrm{O}_{3}$ and 64.6 wt.\% $\mathrm{SiO}_{2}$. LCT pegmatites often contain high contents (>0.9\%) of rubidium and caesium which can also be recovered as byproducts.

Various processes have been developed and reported in the literature to recover lithium from Libearing minerals (Dresler et al., 1998; Distin and Phillips, 1982; Alex and Suri, 1996; Choubey, et al., 2016; Meshram, et al., 2014; Brandt and Haus, 2010). The key challenges associated with the beneficiation of lithium minerals has recently been discussed (Gibson et al., 2017). The processing of spodumene pegmatitic ores requires physical beneficiation which consists of grinding, sizing, flotation, gravity and/or heavy media/magnetic separation techniques to liberate and concentrate spodumene from gangue material. Spodumene is upgraded to make either chemical or ceramic grade concentrate. The type of concentrate is dependent on the impurities in the spodumene crystal lattice and the size distribution of particles. Therefore the beneficiation steps used to concentrate spodumene is very much dependent on the mineralogy.

The most common industrial processes for the extraction of lithium from spodumene requires the conversion of the $\alpha$-spodumene form at elevated temperatures $\left(1000-1100^{\circ} \mathrm{C}\right)$ to the $\beta$-spodumene form to generate a porous material which is more amendable to either an acid or alkaline digestion for extraction of lithium and other elements, such as rubidium and caesium . Lithium can be recovered as a carbonate, hydroxide or chloride from the converted spodumene concentrate with sulfuric acid process (Garrett, 2004) or with sodium carbonate autoclave process (Chen et al., 2011; Olivier and Nenniger, 1979). Less energy intensive process options such as the halide based Sileach process are also being developed which may allow treatment of a wider range of lithium ore feeds (Griffin 2017). However, the deportment of deleterious elements such as fluorine from micas can be problematic and important in considering process paths for treatment. In addition, the dissolution of other metals present in the ore, particularly $\mathrm{Fe}, \mathrm{Mn}$ and $\mathrm{Al}$, requires further purification steps to eliminate them.

In Australia, spodumene concentrates are produced and exported from pegmatite deposits at Greenbushes, Mt Cattlin and Mt Bald in Western Australia. Various companies are set to mine LCTComplex spodumene-type pegmatites from Pilgangoora located in the Pilbara region of Western Australia. The potential production of Li from Pilgangoora's abundant pegmatites containing lepidolite and spodumene is considered a significant Li resource (Table 1).

Table 1: LCT pegmatite deposit resource in the Pilbara craton (Taken from the Geological Survey of Western Australia; AIG, 2017)

\begin{tabular}{lccc}
\hline Mining company & $\begin{array}{l}\text { Ore } \\
(\mathrm{Mt})\end{array}$ & $\begin{array}{l}\text { Average } \\
\text { Grade } \\
\mathrm{Li}_{2} \mathrm{O}(\%)\end{array}$ & $\begin{array}{c}\text { Contained } \\
\mathrm{Li}_{2} \mathrm{O}(\mathrm{Mt})\end{array}$ \\
\hline Altura Mining Limited (Pilgangoora) & 47.50 & 0.99 & 0.47 \\
Pilbara Minerals (Pilgangoora) & 150.6 & 1.24 & 1.86 \\
Pilbara Minerals (Lynas Find) & 5.60 & 1.57 & 0.09 \\
Mineral resources (Wodgina) & 195.85 & 1.18 & 2.32 \\
\hline
\end{tabular}

To facilitate further process development, a comprehensive understanding of the deportment of lithium and associated minerals in potential ore bodies is essential to allow the industry to predict the response of ore reserves to metallurgical treatment options. Conventional chemical analytical and recent field ablation analysis techniques do not provide direct information about lithium deportment and the minerals associated with lithium. Furthermore, lithium is very difficult to analyse using 
conventional x-ray based techniques. In addition, publications using automated mineralogy to characterise Li-bearing ores, the deportment of $\mathrm{Li}$ and mineral textures have until recently been limited. (e.g., Grammatikopoulos et al., 2009; Sandmann and Gutzmer, 2013; Gibson et al., 2017).

This paper describes results from the integrated use of the John de Laeter Centre's analytical and mass spectrometry techniques to characterise Pilgangoora spodumene pegmatite ores. The mineralogical observations are then related to the processing properties of spodumene ores.

\section{Methodology}

Mineral specimens of different Li minerals were collected from sites around Western Australia and first characterised using wet chemical and laser ablation ICPMS techniques to generate a mineral database. This database was then used to define and search for the minerals in Pilgangoora samples. A study on the Li bearing micas have been described elsewhere (Aylmore et al., in press). For clarity a table of the minerals and average compositions used are present in Table 2. Lepidolite represents a solid solution series and intergrowths between the Al-bearing micas of polylithionite and trilithionite, whereas zinnwaldite is the Fe bearing micas ranging from trilithionite - polylithionite series to siderophyllite (Foster, 1960). The different Li-bearing micas and muscovite can be distinguished based on their aluminium and silica ratio as well as elemental impurities associated with them (Aylmore et al., in press).

Table 2: Common lithium-bearing and associated minerals found in pegmatites

\begin{tabular}{|c|c|c|c|c|c|c|c|c|c|c|c|c|c|c|c|c|c|c|c|c|}
\hline \multirow{2}{*}{ Mineral } & \multirow{2}{*}{ Ideal formula } & \multirow{2}{*}{ Source } & $\mathrm{Li}$ & $\mathrm{Na}$ & $\mathrm{Al}$ & $\mathrm{Si}$ & $\mathrm{K}$ & $\mathrm{Mn}$ & $\mathrm{Fe}$ & $\mathrm{Rb}$ & $\mathrm{F}$ & $\mathrm{Be}$ & B & $\mathrm{Mg}$ & $\mathrm{Ca}$ & P & $\mathrm{Ti}$ & $\mathrm{Zn}$ & $\mathrm{Nb}$ & $\mathrm{Cs}$ \\
\hline & & & \multicolumn{9}{|c|}{$\%$} & \multicolumn{9}{|c|}{ ppm } \\
\hline Siderophyllite & $\mathrm{KLiFe}_{2}{ }^{2+} \mathrm{Al}\left(\mathrm{AlSi}_{3} \mathrm{O}_{10}\right)(\mathrm{F}, \mathrm{OH})_{2}$ & unknown & & & 8.3 & 15.5 & 7.2 & 0.4 & 18.6 & 0.7 & 0.2 & & & & & & & & & \\
\hline Albite & $\mathrm{NaAlSi}_{3} \mathrm{O}_{8}$ & Cocanarup (Ravensthorpe) & 0.0 & 7.9 & 9.9 & 29.8 & 0.1 & & & & & 4 & 14 & 1.4 & 1024 & 786 & 1.2 & & & 2 \\
\hline Microcline & $\mathrm{KAISi}_{3} \mathrm{O}_{8}$ & Spargoville (Widgiemooltha) & 0.0 & 0.6 & 9.5 & 29.7 & 13.1 & & & 0.5 & & 3 & 11 & & 113 & 656 & 1.2 & 0.8 & & 197 \\
\hline Muscovite & $\mathrm{KAl}_{2}\left(\mathrm{AlSi}_{3} \mathrm{O}_{10}\right)(\mathrm{OH}, \mathrm{F})_{2}$ & Mt Cattlin (Ravensthorpe) & 0.15 & 0.4 & 16.9 & 21.1 & 8.0 & 0.2 & 1.9 & 1.5 & 0.7 & 16 & 337 & 495 & 1046 & 145 & 611 & 353 & 58 & 513 \\
\hline Biotite & $\mathrm{K}\left(\mathrm{Mg}, \mathrm{Fe}^{2+}\right)_{3}\left(\mathrm{AlSi}_{3} \mathrm{O}_{10}\right)(\mathrm{OH}, \mathrm{F})_{2}$ & Yinnietharra (Gascoyne) & 0.18 & 0.2 & 11.6 & 19.4 & 8.5 & 1.4 & 36.8 & 0.9 & & 5 & 2 & 1034 & 1349 & 39 & 5082 & 998 & 659 & 82 \\
\hline Beryl & $\mathrm{Be}_{3} \mathrm{Al}_{2} \mathrm{Si}_{6} \mathrm{O}_{18}$ & Spargoville (Widgiemooltha) & 0.19 & 0.7 & 9.5 & 29.7 & & & 0.4 & & & $4.6 \%$ & & 736 & & & 111 & 269 & & 2010 \\
\hline Lithian Muscovite & $\mathrm{KLiAl}_{2}\left(\mathrm{AlSi}_{3} \mathrm{O}_{10}\right)(\mathrm{OH}, \mathrm{F})_{2}$ & Cocanarup (Ravensthorpe) & 0.57 & 1.0 & 14.7 & 21.0 & 7.5 & 0.4 & 0.2 & 1.5 & 1.3 & 8 & 127 & 546 & 639 & 61 & 17 & 237 & 78 & 523 \\
\hline "Zinnwaldite" & Siderophyllite-polylithionite series & Cocanarup (Ravensthorpe) & 0.90 & 0.3 & 14.3 & 19.0 & 7.6 & 1.1 & 0.7 & 1.2 & 4.6 & 19 & 189 & 94 & 0 & 77 & 198 & 1166 & 87 & 440 \\
\hline Trilithionite & $\mathrm{K}\left(\mathrm{Li}_{1.5} \mathrm{Al}_{1.5}\right)\left(\mathrm{AlSi}_{3} \mathrm{O}_{10}\right)(\mathrm{F}, \mathrm{OH})_{2}$ & Londonderry (Coolgardie) & 0.91 & 0.1 & 15.7 & 21.0 & 8.0 & 1.7 & 0.3 & 2.8 & 2.7 & 11 & 22 & 46 & 87 & 94 & 90 & 1148 & 39 & 2247 \\
\hline Elbaite & $\mathrm{NaLi}_{1.5} \mathrm{Al}_{1.5} \mathrm{Al}_{6} \mathrm{Si}_{6} \mathrm{O}_{18}\left(\mathrm{BO}_{3}\right)_{3}(\mathrm{OH})_{4}$ & Mt Cattlin (Ravensthorpe) & 1.06 & 1.5 & 23.7 & 19.1 & 0.01 & 0.1 & & & & 18 & $3.5 \%$ & 2 & 2985 & 173 & 3 & 3 & 3 & \\
\hline "Lepidolite" & Trilithionite-polylithionite series & Cocanarup (Ravensthorpe) & 2.59 & 0.2 & 17.5 & 28.5 & 10.7 & 0.3 & 0.2 & 2.7 & 7.3 & 31 & 325 & 65 & & 149 & 21 & 118 & 138 & 2608 \\
\hline Polylithionite & $\mathrm{K}\left(\mathrm{Li}_{2} \mathrm{Al}\right)\left(\mathrm{AlSi}_{3} \mathrm{O}_{10}\right)(\mathrm{F}, \mathrm{OH})_{2}$ & Grosmont (Coolgardie) & 3.35 & 0.3 & 14.4 & 28.3 & 10.6 & 0.5 & 0.1 & 1.4 & 9.6 & 75 & 11 & 90 & & & 847 & 44 & 174 & 1819 \\
\hline Petalite & $\mathrm{LiAlSi}_{4} \mathrm{O}_{10}$ & Londonderry (Coolgardie) & 2.09 & & 8.7 & 36.7 & & & & & & & & & & & & & & \\
\hline Spodumene & $\mathrm{LiAlSi}_{2} \mathrm{O}_{6}$ & Ravensthorpe & 3.36 & 0.09 & 14.2 & 29.9 & 0.09 & 0.1 & 0.2 & & & 5 & 18 & 61 & 131 & & 35 & 19 & & 7 \\
\hline & & & 3.52 & 0.06 & 14.0 & 29.8 & & 0.04 & 1.5 & & & 1 & 10 & 6 & & & 21 & 3 & & \\
\hline
\end{tabular}

Of note is that, apart from the lithium content, many of these minerals contain elements such as Mn, $\mathrm{Fe}, \mathrm{Rb}, \mathrm{F}$ and $\mathrm{Cs}$ that can either be a by-product if in high concentration (e.g. $\mathrm{Rb}, \mathrm{Cs}$ ) or impinge on the method of processing (e.g. sulfate roasting of micas generating HF gas).

\subsection{Ore samples}

Samples were taken from outcrops of pegmatite within Pilbara Minerals Ltd Pilgangoora Project and collected by Lithium Australia NL and combined. The samples represent the spodumene zone lithologies within LCT-Complex spodumene-type pegmatites (Cerny and Ercit, 2005) that are part of the mineral resource that will be mined by Pilbara Minerals Ltd. Lithium Australia NL has a strategic alliance with Pilbara Minerals Ltd to assist the development of the halogen-based Sileach ${ }^{\mathrm{TM}}$ process, which can recover Li from spodumene without roasting. Pilbara Minerals is currently building a 2 Mtpa concentrate plant at Pilgangoora to produce a chemical grade $6 \mathrm{wt} \% \mathrm{Li}_{2} \mathrm{O}$ spodumene concentrate and a tantalite $30 \% \mathrm{Ta}_{2} \mathrm{O}_{5}$ concentrate (Pilbara Minerals Ltd, 2017).

The combined sample was categorised into three subsamples based on the colour and texture. These subsamples were treated and characterised separately (Figure 1). 

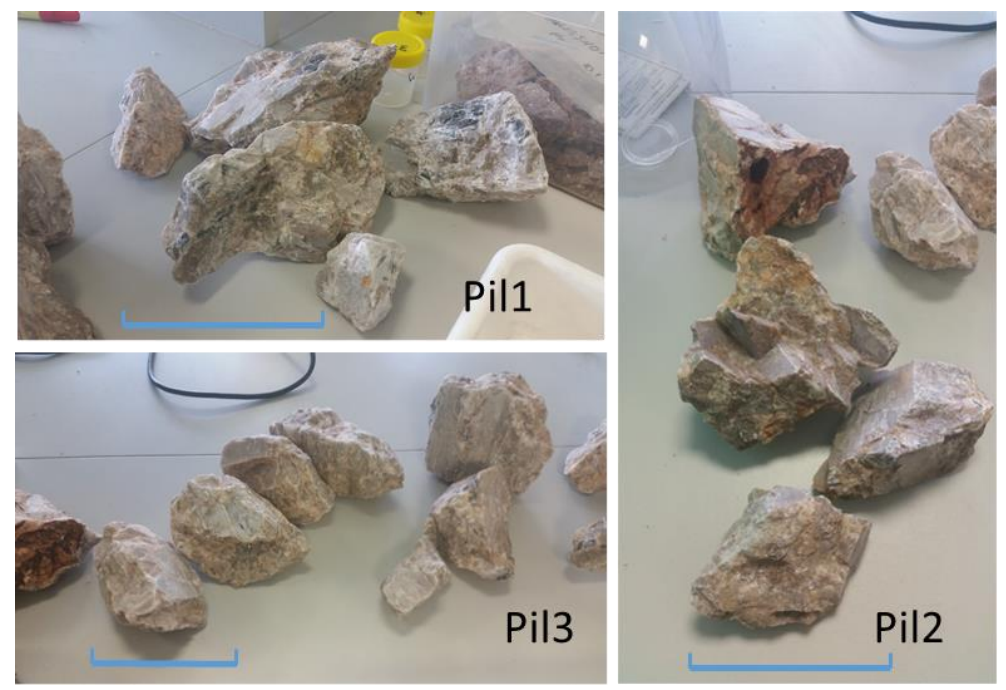

Figure 1: Rock specimens of the Pilgangoora pegmatite split into three different samples. Pill contains dark zones with micaceous minerals present. Pil2 is rich in spodumene (pinkish anhedral crystals) whereas Pil3 contains high quartz and feldspar (whitish) content. Scales: $5 \mathrm{~cm}$.

\subsection{Sample preparation}

The samples were first crushed to pass a $3.5 \mathrm{~cm}$ screen size. They were then subjected to electrodynamic fragmentation (using SelFrag ${ }^{\mathrm{TM}}$ ) and screened to pass a $4 \mathrm{~mm}$ stainless-steel sieve. The electrodynamic fragmentation technique preserves the original crystal morphology and shape, crystal structure and physical and textural features, and allows the study of mineral in their nature form which is often sacrificed during grinding and milling. The electrodynamic fragmentation approach has been successfully used in both geological and metallurgical applications (e.g. Lastra and Cabri, 2003; Chernet, 2010; Wang et al., 2012; Sandmann \& Gutzmer 2013; Brandt \& Haus, 2010; Aylmore et al., in press).

Representative subsamples were split for detailed bulk mineralogical evaluation and chemical analyses. A further subsample was sieved through a standard screen series to produce nine size fractions for mineral liberation characteristic studies. Figure 2 shows the particle size distribution following electrodynamic fragmentation where a large percentage of the material resides in the coarse fraction with minimal fines produced. All three samples have a similar particle distribution.

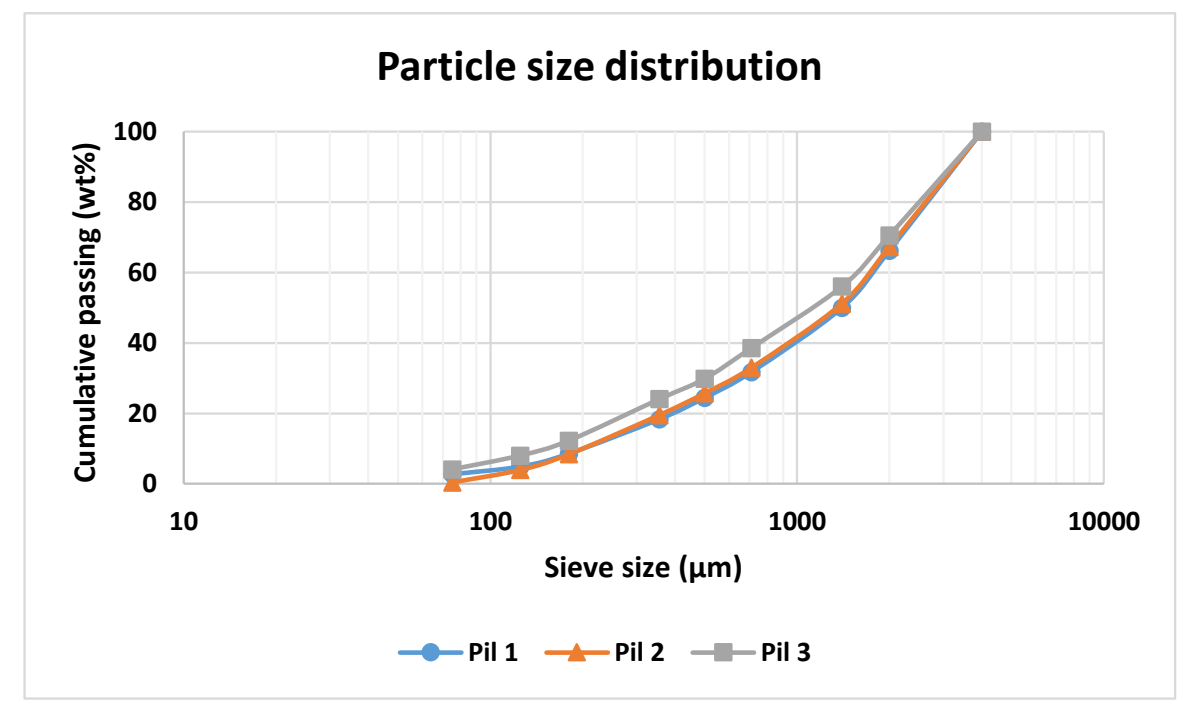

Figure 2: Particle size distribution for all three subsamples.

Polished section mounts of the sized fractions were made and studied separately to determine the relationship of gangue minerals to the Li-bearing silicates and deportment of lithium and impurity 
element associations with them. For the coarse size fractions $(\geq 500 \mu \mathrm{m})$ at least 100 particles where measured in multiple polished mounts ( 2 to 4 polished mounts examined) to improve particle statistics and confidence in the results. Comparisons of the modal mineralogy between polished section mounts of the same size fraction were assessed using the Chi-squared goodness-of-fit test to ensure the reproducibly of results and were observed not to be significantly different.

\subsection{Bulk analyses}

Chemical analyses on Pilgangoora samples were undertaken using a combination of standard mixed acid digest - peroxide fusion techniques and ICP- MS or ICP - OES spectrometry to determine major elements $(\mathrm{Ca}, \mathrm{Fe}, \mathrm{K}, \mathrm{Al}, \mathrm{Mg}, \mathrm{Mn}, \mathrm{P}, \mathrm{S}, \mathrm{Si}$, Ti and $\mathrm{Ba})$ and $\mathrm{Li}$ contents using the services of Bureau Veritas Minerals Pty Ltd.

$\mathrm{X}$-ray powder diffraction (XRPD) studies were performed on ore samples using $\mathrm{Cu} \mathrm{K} \alpha$ radiation and a Bruker D8 Advance diffractometer with a graphite diffracted beam monochromator. Sample preparation involved lightly crushing the samples in a mortar and pestle followed by micronizing in ethanol to generate fine powders suitable for quantitative mineralogy analyses. The powders were backfilled into sample holders and pressed before scanning.

The phase composition was determined using the search/match software Diffrac Eva with ICDD powder diffraction data base. The phase abundance was quantified by Rietveld refinement using Topas $^{\mathrm{TM}}$ software (version 5.0, Bruker Advanced X-ray Solutions). Chemical compositions of the structures were adjusted to match the average composition observed in LA-ICPMS analyses where possible.

\subsection{Analytical approach}

A combination of the TESCAN Integrated Mineral Analyser (TIMA), Tescan Lyra - FIB-SEM with Time-of-Flight Secondary Ion Mass Spectrometry (ToF-SIMS) and laser ablation inductively coupled plasma mass spectrometry (LA-ICPMS) were used to characterise the mineralogy (Figure 3).

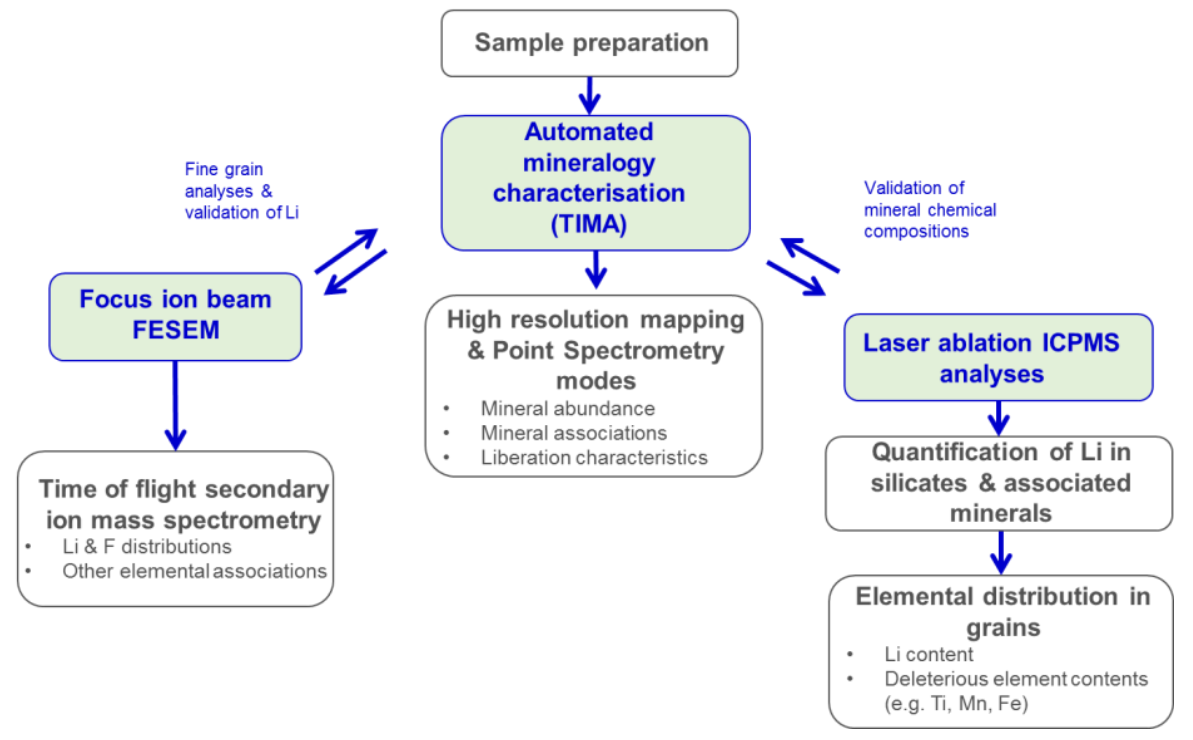

Figure 3: Outline of mineralogical procedures used to study the deportment/distribution of lithium and deleterious element contents in samples.

The TIMA is a high resolution Field Emission Scanning Electron Microscope (FESEM) equipped with four fully integrated silicon drift Energy Dispersive Spectroscopy (EDS) detectors designed for automated mineralogy. The TIMA measures mineral abundance, size-by-size liberation, and mineral associations, and carries out searches for mineral phases automatically on multiple samples. Depending upon the mode of operation, TIMA measurements use a combination of X-ray spectral analysis and backscattered electron (BSE) imaging to identify individual grains and locate grain boundaries before comparing the collected spectral information to a classification scheme. Lithium is very difficult to analyse using conventional X-ray based techniques. Hence the Al-Si composition 
were used to classify and map the spodumene. Similarly, other lithium bearing minerals, such as the $\mathrm{Li}$ bearing micas, were classified base on their elemental composition other than lithium. The Li content was confirmed with other techniques described below.

The detection of Li in minerals was assessed by Time-of-Flight Secondary Ion Mass Spectrometry (ToF-SIM) mounted on a Tescan Lyra - FIB-SEM. FIB-SEM based ToF-SIMS, or FIB-ToF-SIMS, is capable of high spatial resolution elemental mapping (reported lateral resolution $<50 \mathrm{~nm}$, depth resolution <20 nm, detection limit < $10 \mathrm{ppm}$ )(Whitby, et al., 2012; Alberts et al 2014). SIMS elemental mapping was performed using a high resolution $\mathrm{Ga}^{+}$focused ion beam which was rastered over selected areas on the polished mount. Charged ions from the ablated surface are then analysed by ToF-SIMS to characterise the lithium content and distribution of other elements of interest (e.g Fe, Mn, F).

Based on the mineralogy identified with the TIMA and ToF-SIMS analysis, selected grains were evaluated by LA-ICPMS to quantify the concentrations of lithium and the distribution of associated elements. LA-ICPMS analysis was carried out using a Resonetics Resolution $193 \mathrm{~nm}$ excimer laser ablation system coupled with an Agilent 7700s quadrapole ICPMS (75 micron diameter spot, frequency $7 \mathrm{~Hz}$, fluence of $3.2 \mathrm{j} / \mathrm{cm}^{2}, 35 \mathrm{~s}$ ablation, $20 \mathrm{~s}$ baseline). Ablation was performed in an ultrahigh purity He atmosphere, and the resulting aerosol was mixed with an Ar carrier gas before introduction to the ICPMS. Spot analysis was carried out on different mineral grains or particles. Grain compositions were determined using NIST 610 standard and stoichiometry standardised using Si for each mineral derived from the data of other analytical techniques (wet chemical and EDS analyses).

\section{$3 \quad$ Analyses of ore sample}

\subsection{Bulk chemical composition}

The chemical composition of the main elements found in pegmatites for the three subsamples varied and is shown in Table 3. The average Li grade in the first two samples are $1.5 \mathrm{wt} \%$, whereas the third contains $1 \mathrm{wt} \%$. These Li grades $\left(2.1-3.2 \% \mathrm{Li}_{2} \mathrm{O}\right)$ are slightly higher than those reported for the average Pilgangoora ore (Table 1). F contents are low, ranging from 0.03 to $0.11 \mathrm{wt} \%$. Pill sample contains higher $\mathrm{Ca}, \mathrm{Be}, \mathrm{Ba}, \mathrm{F}, \mathrm{Fe}, \mathrm{Mn}, \mathrm{Mg}, \mathrm{Cs}, \mathrm{Mn}$ and $\mathrm{Zn}$ contents, but lower $\mathrm{Ta}, \mathrm{Nb}$ and $\mathrm{Na}$ contents relative to the other subsamples. Pil3 sample has notable high $\mathrm{Rb}$ and $\mathrm{K}$ contents. Spodumene often contains a small amount of $\mathrm{Fe}$ which give it a green colour. Low Fe spodumene is white/grey or pinkish, if $\mathrm{Mn}$ is present. The $\mathrm{Nb}$, Ta and Sn content in all three samples are low. Pil2 has a slightly higher silicon content. 
Table 3: Bulk chemical analysis of samples

\begin{tabular}{|c|c|c|c|c|c|c|c|c|c|}
\hline \multirow[b]{2}{*}{ Element } & \multicolumn{4}{|c|}{ Majors } & \multirow[b]{2}{*}{ Element } & \multicolumn{4}{|c|}{ Minors } \\
\hline & Units & Pil1 & Pil2 & Pil3 & & Units & Pill & Pil2 & Pil3 \\
\hline $\mathrm{Li}$ & $\%$ & 1.49 & 1.50 & 0.99 & $\mathrm{Mn}$ & ppm & 2020 & 994 & 656 \\
\hline $\mathrm{Si}$ & $\%$ & 29.7 & 34.3 & 30.0 & Cs & ppm & 233 & 109 & 218 \\
\hline $\mathrm{Fe}$ & $\%$ & 0.12 & 0.11 & 0.08 & $\mathrm{Be}$ & ppm & 585 & 61 & 62 \\
\hline $\mathrm{Al}$ & $\%$ & 9.52 & 9.22 & 7.89 & $\mathrm{Sn}$ & ppm & 220 & 200 & 210 \\
\hline $\mathrm{Ca}$ & $\%$ & 1.42 & 0.12 & 0.09 & $\mathrm{P}$ & ppm & 150 & 450 & 350 \\
\hline $\mathrm{Mg}$ & $\%$ & 0.24 & 0.03 & 0.04 & $\mathrm{Ta}$ & ppm & 108 & 279 & 197 \\
\hline $\mathrm{Na}$ & $\%$ & 0.75 & 1.1 & 1.14 & $\mathrm{Zn}$ & ppm & 130 & 100 & 58 \\
\hline K & $\%$ & 1.84 & 1.39 & 2.73 & $\mathrm{Nb}$ & ppm & 25.5 & 45.5 & 39 \\
\hline $\mathrm{C}$ & $\%$ & 0.4 & 0.02 & 0.02 & Co & ppm & 40 & 60 & 70 \\
\hline $\mathrm{F}$ & $\%$ & 0.11 & 0.05 & 0.03 & $\mathrm{Ba}$ & ppm & 52 & 9 & 3 \\
\hline $\mathrm{Rb}$ & $\mathrm{ppm}$ & 2700 & 2360 & 2740 & & & & & \\
\hline
\end{tabular}

\subsection{Assessment of mineral content}

A comparison of the XRPD patterns of the three spodumene pegmatite subsamples is shown in Figure 4. The samples are made up of predominately spodumene, quartz, and feldspars, with mica (shown here as muscovite), calcite and beryl present in various proportions, depending on the sample.

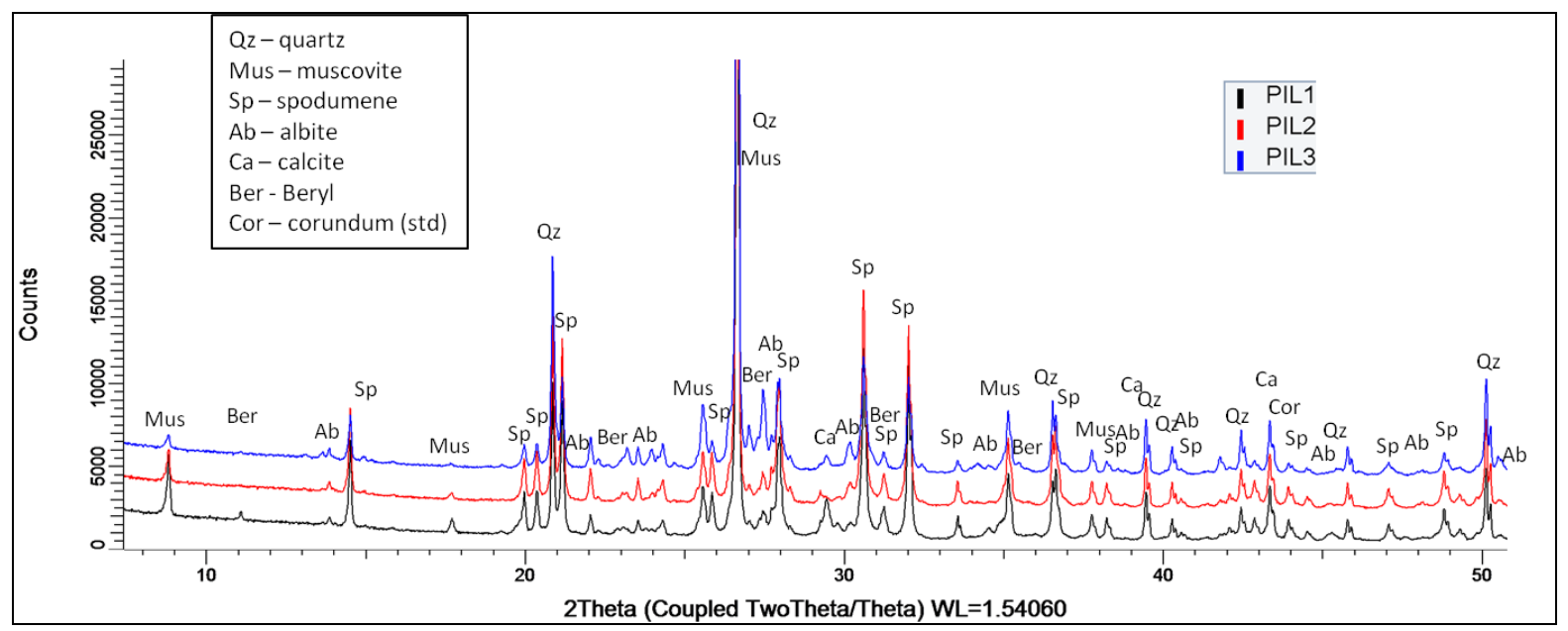

Figure 4: X-ray powder diffraction patterns of the three samples.

The relative abundance was quantified by Rietveld analysis and are shown later in Table 4 . The fit between the observed and calculated pattern data were good $(\mathrm{Rwp}=9.99 \%)$. Spodumene was refined using structure data defined by Cameron et al (1973). Corundum was added and used as an internal standard for mineral quantification and clarifying the unit cell parameters. The unit cell dimension derived from modelling the spodumene structure (space group C2/c: a $9.468 \AA$, b $8.394 \AA$, c $5.222 \AA$, beta $110.17^{\circ}$ ) reside in the range of values reported in the literature for the alpha monoclinic form (Cameron et al., 1973; Charoy et al., 1992). Feldspar was modelled based on the rubidium containing feldspar rubicline (Gasperin, 1971; Teertstra et al., 1998; Kyono \& Kimata, 2001) because high values of $\mathrm{Rb}$ were observed in feldspar grains as discussed later. In addition to muscovite, trace amounts of polylithionite and trilithionite are present mainly in the Pill sample. Pill sample also contains measurable beryl and calcite contents.

The mineralogical composition of the samples acquired from TIMA and XRPD analysis is shown in Table 4. The mineral mass of a phase by TIMA is calculated based on area $\%$ in polish sectioned mounts using an assumed density for each identified mineral. All samples are made up of predominately spodumene, quartz and feldspars as observed by XRPD data. The Pill contains micaceous minerals and calcite, whereas Pil3 is more abundant in feldspars. Pil2 is similar to Pil3 but with a higher concentration of spodumene and less feldspar. The mineralogical result for each sample 
from the TIMA mineral analysis and XRPD measurements are generally in good agreement. XRPD cannot distinguish accurately the difference between the different $\mathrm{Li}$ bearing micas. Therefore the muscovite value used in the table represents a combination of the different micas, whereas the TIMA mica data are characterised based on chemical signatures in the mineral classification scheme. The modelling of the XRD patterns required correcting for preferred orientation of micas, which can have an effect on the accuracy of this method for mineral quantitate analyses. Hence, some differences in mineral abundance between XRPD and TIMA can be attributed to errors in the calculated mica content.

Table 4: Modal mineral abundance from TIMA and XRPD studies

\begin{tabular}{|c|c|c|c|c|c|c|}
\hline \multirow{2}{*}{$\begin{array}{l}\text { Primary phases / } \\
\text { Mass of phase } \\
(\%)\end{array}$} & \multicolumn{2}{|c|}{ Pilgangoora 1} & \multicolumn{2}{|c|}{ Pilgangoora 2} & \multicolumn{2}{|c|}{ Pilgangoora 3} \\
\hline & TIMA & XRD & TIMA & XRD & TIMA & XRD \\
\hline Spodumene & 38.86 & 44 & 43.57 & 50 & 32.75 & 30 \\
\hline Quartz & 28.39 & 27 & 32.99 & 31 & 30.49 & 32 \\
\hline Albite & 10.34 & 7 & 12.07 & 11 & 10.66 & 12 \\
\hline K, Rb-Feldspar & 6.52 & 5 & 4.94 & 3 & 21.18 & 19 \\
\hline Muscovite & 2.83 & 8 & 5.08 & 3 & 3.67 & 6 \\
\hline${ }^{1}$ Lepidolite & 4.98 & - & 0.09 & - & 0.11 & - \\
\hline Trilithionite & 3.50 & - & 0.34 & - & 0.21 & - \\
\hline Polylithionite & 0.21 & - & 0.13 & - & 0.41 & - \\
\hline Calcite & 2.62 & 3 & 0.00 & & 0.03 & \\
\hline Beryl & 0.86 & $<2$ & 0.27 & 0.3 & 0.10 & \\
\hline Anorthite & 0.47 & & 0.07 & & 0.08 & \\
\hline Apatite & 0.11 & & 0.21 & & 0.10 & \\
\hline Petalite & 0.05 & & 0.07 & & 0.04 & \\
\hline $\begin{array}{l}\text { Elbaite } \\
\text { /Cookeite }\end{array}$ & 0.02 & & 0.05 & & 0.08 & \\
\hline $\begin{array}{l}\text { Columbite- } \\
\text { Tantalite }\end{array}$ & 0.05 & & 0.03 & & 0.02 & \\
\hline Zinnwaldite & 0.00 & & 0.04 & & 0.02 & \\
\hline Cassiterite & 0.01 & & 0.01 & & 0.04 & \\
\hline Others & 0.05 & & 0.02 & & 0.01 & \\
\hline Total & 100 & & 100 & & 100 & \\
\hline
\end{tabular}

The accuracy and consistency of the derived data calculated by TIMA was compared with the whole rock bulk chemistry and the results are shown in Table 6 . An $\mathrm{R}^{2}$ value is presented for each sample. This value describes the deviation of the results from a perfectly linear relationship $\left(R^{2}=1\right)$. The minerals in the mineral classification file used to classify phases in the polished mounts have fixed average chemical compositions. Hence, variations observed in some elements, particularly for sample Pil3, such as Cs content in micas, feldspar and beryl grains, were not modelled and account for some variation in some values. Overall the data are in good agreement and yield confidence in the results. 
Table 5: Calculated TIMA chemistry versus measured chemical analysis

\begin{tabular}{cccccccc}
\hline Element & Units & \multicolumn{2}{c}{ Pil1 } & \multicolumn{2}{c}{ Pil2 } & \multicolumn{2}{c}{ Pil3 } \\
\hline $\mathrm{Li}$ & $\%$ & Chem & TIMA & Chem & TIMA & Chem & TIMA \\
$\mathrm{Si}$ & $\%$ & 29.7 & 1.5 & 1.5 & 1.6 & 1.0 & 1.1 \\
$\mathrm{Fe}$ & $\%$ & 0.12 & 0.0 & 0.11 & 0.0 & 0.08 & 0.02 \\
$\mathrm{Al}$ & $\%$ & 9.5 & 9.1 & 9.2 & 8.8 & 7.9 & 8.1 \\
$\mathrm{Ca}$ & $\%$ & 1.4 & 1.2 & 0.12 & 0.2 & 0.09 & 0.1 \\
$\mathrm{Mg}$ & $\%$ & 0.2 & 0.1 & 0.03 & 0.0 & 0.04 & 0.01 \\
$\mathrm{Na}$ & $\%$ & 0.8 & 0.9 & 1.1 & 1.0 & 1.1 & 0.9 \\
$\mathrm{~K}$ & $\%$ & 1.8 & 1.8 & 1.4 & 1.2 & 2.7 & 3.2 \\
$\mathrm{C}$ & $\%$ & 0.4 & 0.3 & 0.02 & 0.0 & 0.02 & 0.0 \\
$\mathrm{~F}$ & $\%$ & 0.11 & 0.48 & 0.05 & 0.09 & 0.03 & 0.07 \\
$\mathrm{Rb}$ & $\mathrm{ppm}$ & 2700 & 2789 & 2360 & 2300 & 2740 & 2412 \\
$\mathrm{Mn}$ & $\mathrm{ppm}$ & 2020 & 3180 & 994 & 1388 & 656 & 510 \\
$\mathrm{Cs}$ & $\mathrm{ppm}$ & 233 & 300 & 109 & 36 & 218 & 18 \\
$\mathrm{Be}$ & $\mathrm{ppm}$ & 585 & 368 & 61 & 114 & 62 & 50 \\
$\mathrm{Sn}$ & $\mathrm{ppm}$ & 220 & 62 & 200 & 72 & 210 & 257 \\
$\mathrm{P}$ & $\mathrm{ppm}$ & 150 & 189 & 450 & 359 & 350 & 176 \\
$\mathrm{Ta}$ & $\mathrm{ppm}$ & 108 & 132 & 279 & 116 & 197 & 83 \\
$\mathrm{Nb}$ & $\mathrm{ppm}$ & 25.5 & 149 & 45.5 & 98 & 39 & 97 \\
& & & $\mathrm{R}^{2}=0.94$ & $\mathrm{R}^{2}=0.96$ & & $\mathrm{R}^{2}=0.99$ \\
\hline
\end{tabular}

\subsubsection{Morphology and texture of particles}

Figure 5 shows representative mineral composition maps of all three subsamples in the polished mounts for the $+500 \mu \mathrm{m}$ fractions, together with close up of major spodumene grains associations with other minerals. All three samples are abundant in spodumene with many particles low in other mineral inclusions, even at the coarse size fractions. In Pill some of the spodumene particles have undergone alteration with spodumene being replaced by micaceous minerals of muscovite, lepidolite and trilithionite, as well as calcite. These alterations occur along margins and fractures and form aggregates or veinlets of mixed assemblages (Figure $5 \mathrm{a} \& \mathrm{~b}$ ). The calcite present is associated with spodumene.

In both Pil2 and Pil3 samples, the spodumene particles are generally free of mineral impurities (Figure 5 c \& d) except some intergrowths of quartz, feldspar and spodumene are evident in the Pil2 sample and to a lesser extend Pil3 (Figure 5 e \& f). Quartz and feldspar grains are coarse with a high proportion moderately free of other minerals. The amount of spodumene liberated from gangue materials is discussed later. Free grains of beryl, cassiterite and tantalite were also observed and are discussed later. 

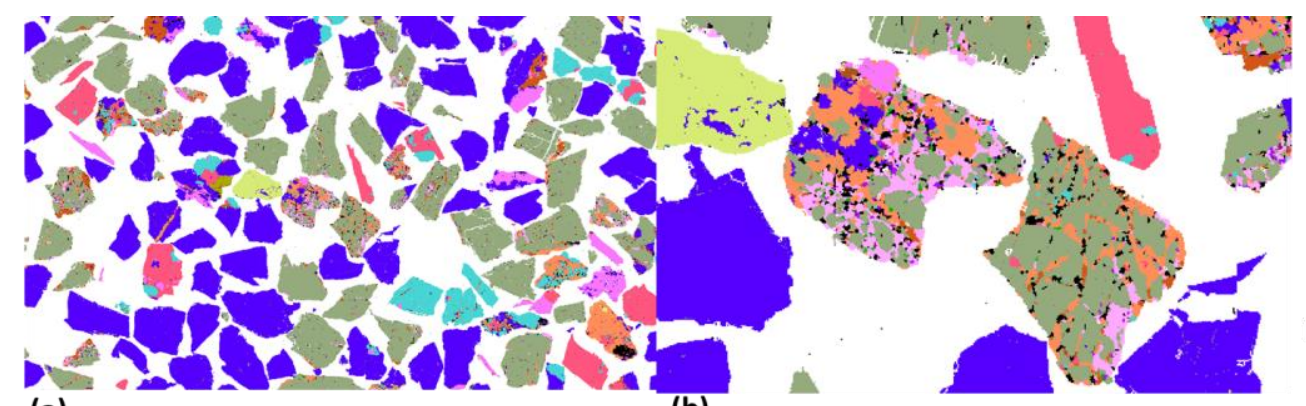

(a)

(b)

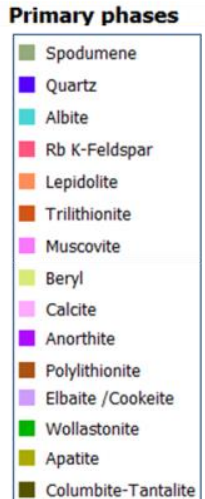

(c)

(d)

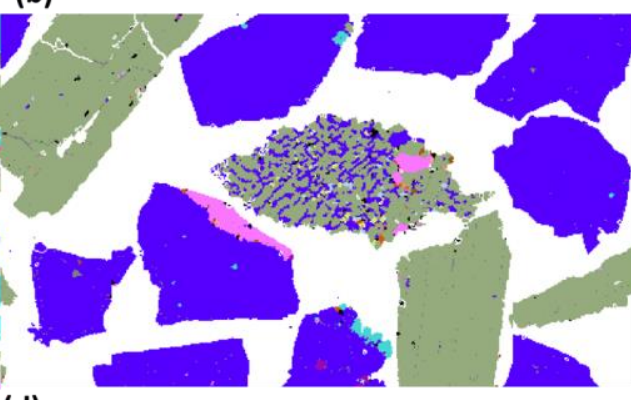

Columbite-Tantalite

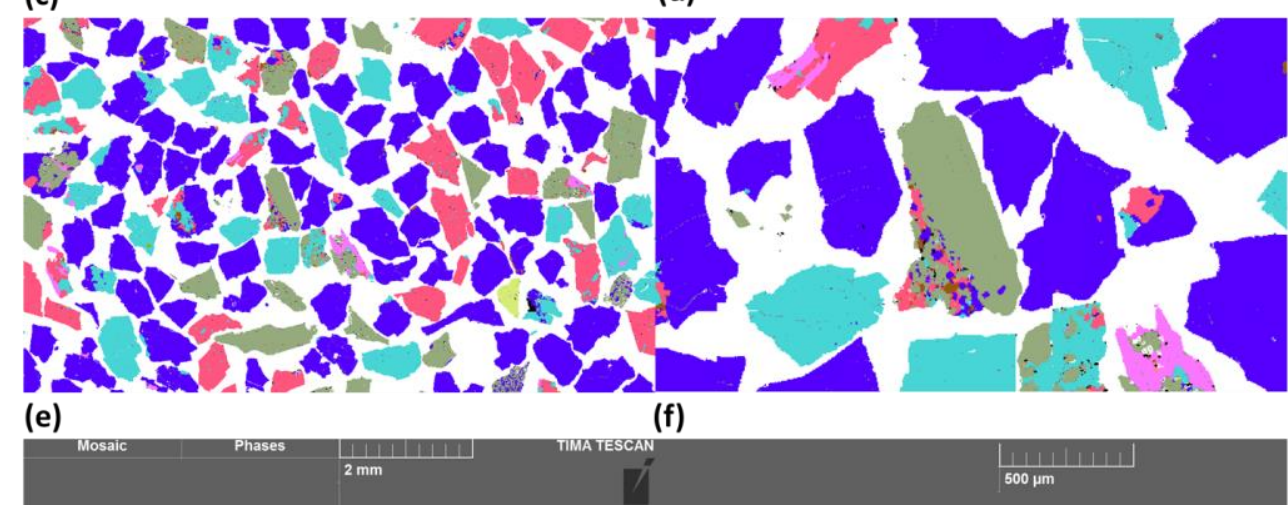

Figure 5: TIMA mineral composition map showing liberated spodumene and gangue minerals grains in the $+500 \mu \mathrm{m}$ size fraction for all three samples $(\mathrm{a}, \mathrm{c}, \mathrm{e})$. The mineral maps on the right-hand side show close up of the different mineral textures observed in some of the spodumene grains $(b, d, f)$.

\subsection{Spodumene composition}

The quantity of mineral and elemental impurities within spodumene grains is important as they will have to be managed in any chemical process for decomposing spodumene and extracting lithium.

The chemical analyses of spodumene for all three subsamples were obtained by LA-ICPMS and then the pyroxene structure formula $\mathrm{XYZ}_{2} \mathrm{O}_{6}$ used to calculate the mineral stoichiometry. A comparison of the Pilgangoora spodumene composition with some mineral specimens and literature compositions are shown in a Li-Al-Si ternary plot in Figure 6. The average chemical composition from the LA-ICPMS analysis for spodumene in the Pilgangoora samples, together with analysis from mineral specimens, is shown in Table 6. Figure 6 shows that the data from this study fall to the left of the idea formula, indicating some lithium deficiency in the spodumene structure. In the pyroxene formula $\mathrm{X}$ represents $\mathrm{Na}, \mathrm{Ca}, \mathrm{Mn}^{2+}, \mathrm{Fe}^{2+}, \mathrm{Mg}$, and $\mathrm{Li}$ in the distorted 6- to 8- coordinated M2 site; $\mathrm{Y}$ represents $\mathrm{Mn}^{2+}, \mathrm{Fe}^{2+}$, $\mathrm{Mg}, \mathrm{Fe}^{+}, \mathrm{Al}, \mathrm{Cr}$, and $\mathrm{Ti}$ in the octahedral $\mathrm{Ml}$ site; and $\mathrm{Z}$ represents $\mathrm{Si}$ and $\mathrm{Al}$ in the tetrahedral site. Spodumene compositions do not show any significant deviation from the ideal formula $\mathrm{LiAlSi}_{2} \mathrm{O}_{6}$ (Deer et al., 1978; London \& Burt, 1982). However, Li is always deficient relative to the theoretical value for the large majority of spodumene compositions reported in the literature (Charoy et al., 1992).

The spodumene in the Pilgangoora samples contain around $3 \mathrm{wt} \% \mathrm{Li}\left(\mathrm{Li}_{2} \mathrm{O} 5.75 \mathrm{wt} \%\right)$ which is less than the maximum reported in the literature $\left(\mathrm{Li}_{2} \mathrm{O} 8 \mathrm{wt} \%\right)$. They also contain notable concentrations of $\mathrm{Na}, \mathrm{Mn}$ and $\mathrm{Fe}$. Some high concentrations of $\mathrm{Na}$ in secondary spodumene after petalite have been 
reported in the early literature (Cerny \& Ferguson, 1972). Impurities of iron and manganese, which substitute for $\mathrm{Al}$ in the crystal structure yield yellow to green coloured and pink to lilac spodumene respectively. Some of the impurities detected $(\mathrm{Rb}, \mathrm{Cs}, \mathrm{K})$ are associated with fine inclusions of other minerals within the spodumene grains which have been ablated along with spodumene.

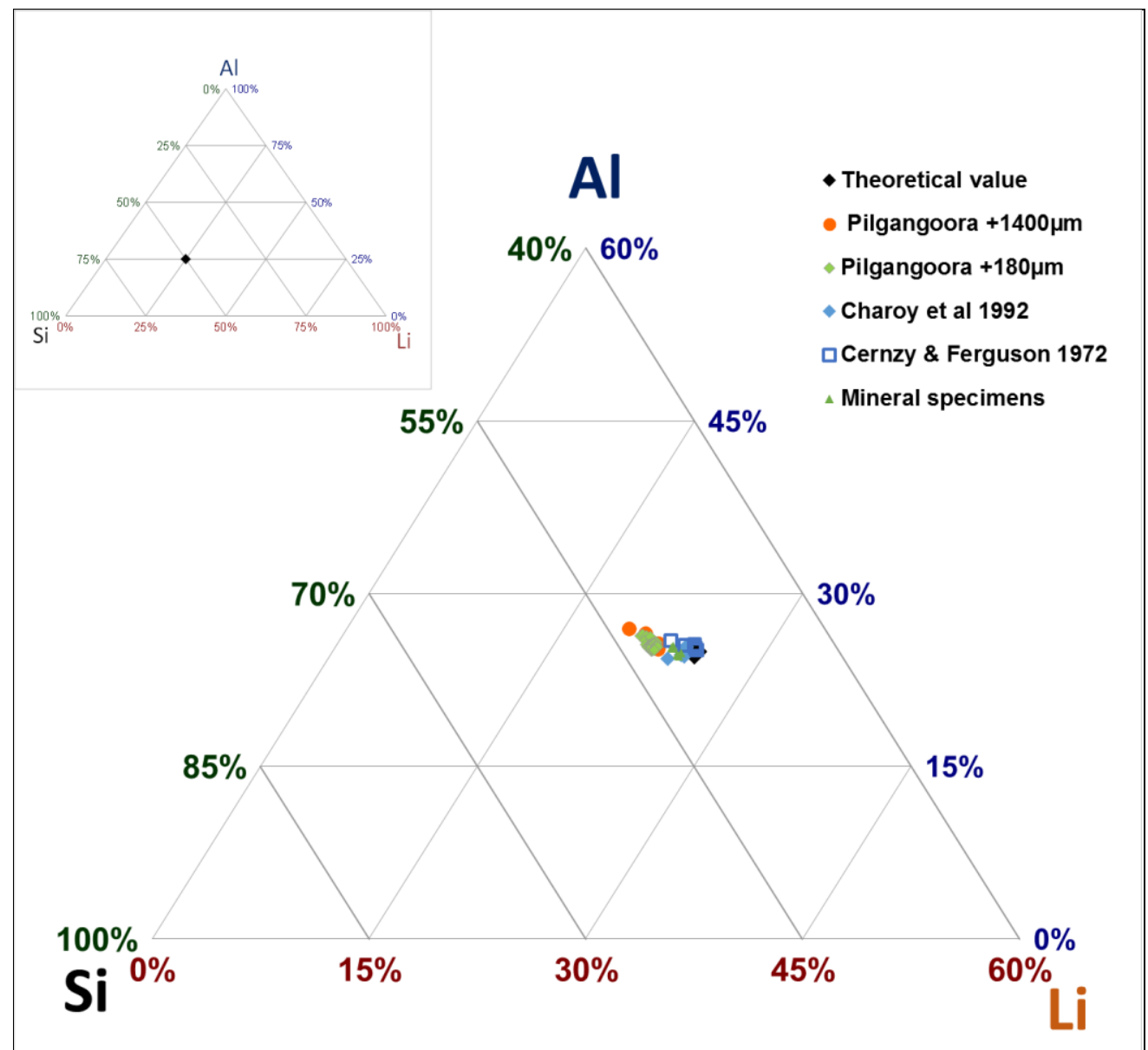

Figure 6: Comparison of spodumene composition reported on a Li-Al-Si ternary plot (atomic proportions). Data for the spodumene mineral specimens, ore samples and some literature compositions are also shown.

Table 6: Average chemical composition Pilgangoora samples and standard derivation from LA-ICPMS analysis

\begin{tabular}{|c|c|c|c|c|c|c|c|c|c|}
\hline \multirow{2}{*}{\multicolumn{6}{|c|}{ Pilgangoora samples (80 points) }} & \multicolumn{4}{|c|}{ Mineral specimens $^{1}$} \\
\hline & & & & & & \multicolumn{2}{|c|}{ Spodumene (White) } & \multicolumn{2}{|c|}{ Spodumene (green) } \\
\hline & & Average & SD & Min & Max & Average & SD & Average & SD \\
\hline $\mathrm{Li}$ & $\%$ & 3.13 & 0.03 & 3.08 & 3.19 & 3.36 & 0.02 & 3.52 & 0.02 \\
\hline $\mathrm{Al}$ & $\%$ & 14.1 & 0.1 & 13.8 & 14.4 & 14.2 & 0.08 & 14.0 & 0.12 \\
\hline $\mathrm{Si}$ & $\%$ & 30.2 & 0.2 & 29.8 & 30.6 & 29.9 & 0.05 & 29.8 & 0.05 \\
\hline $\mathrm{K}$ & ppm & 63 & 47 & 16 & 190 & 879 & 252 & 19 & 11 \\
\hline $\mathrm{Na}$ & ppm & 779 & 146 & 454 & 1068 & 935 & 93 & 582 & 50 \\
\hline $\mathrm{Mg}$ & ppm & 16 & 27 & 1 & 143 & 61 & 44 & 6 & 6 \\
\hline $\mathrm{Ca}$ & ppm & 26 & 101 & 0 & 650 & 131 & & 0 & \\
\hline $\mathrm{Ti}$ & ppm & 2 & 1 & 0.4 & 8 & 35 & 4 & 21 & 4 \\
\hline $\mathrm{Mn}$ & ppm & 879 & 174 & 380 & 1509 & 992 & 104 & 439 & 137 \\
\hline $\mathrm{Fe}$ & ppm & 583 & 321 & 81 & 1475 & 2279 & 46 & 15083 & 661 \\
\hline${ }^{2} \mathrm{Rb}$ & ppm & 5 & 8 & $<0.2$ & 29 & 38 & 34 & $<0.2$ & \\
\hline${ }^{3} \mathrm{Cs}$ & ppm & 1 & 1 & $<0.01$ & 5 & 6.5 & 9 & $<0.01$ & \\
\hline
\end{tabular}




\subsection{Assessment of mineral constituents associated with spodumene grains}

The composition and elemental distribution of micas and calcite minerals associated with fractures and veinlets in spodumene grains were examined in detail by ToF-SIMS analysis and an example is shown in Figure 7. The lepidolite veinlets and aggregates contain $\mathrm{K}, \mathrm{Rb}, \mathrm{Cs}, \mathrm{F}$ and moderate amounts of $\mathrm{Mn}$, disseminated with $\mathrm{Li}$, which are typical composition for $\mathrm{Li}$ bearing micas. $\mathrm{Mg}$ is also enriched and associated with $\mathrm{Rb}$ and $\mathrm{Cs}$. The $\mathrm{K}, \mathrm{Mg}, \mathrm{Cs}, \mathrm{F}$ and $\mathrm{Rb}$ composition in lepidolite grains varies within the veinlets. The surrounding spodumene grains consist of $\mathrm{Li}, \mathrm{Al}, \mathrm{Si}$ and are barren of the other elements. ToF-SIMS analysis of calcite veinlets detected $\mathrm{F}$ and $\mathrm{Mg}$ contents (not shown here). The lithium content measured by LA-ICPMS analysis in of some trilithionite and lepidolite grains within spodumene was high at $1.3 \mathrm{wt} \%$ and $1.86 \mathrm{wt} \%$ respectively.

The distribution of caesium and rubidium in the samples was assessed. Caesium is associated with the mica minerals and beryl grains. The estimated caesium concentrations in a few beryl grains measured by LA-ICPMS analysis was $1300 \mathrm{ppm}$. Rubidium is associated with both feldspar and Li bearing mica grains. Samples Pil2 and Pil3 have higher Rb content (1.0-1.2 wt\%) in feldspars compared with the Pill sample $(0.2 \mathrm{wt} \%)$, which indicates some variation in the conditions of formation.
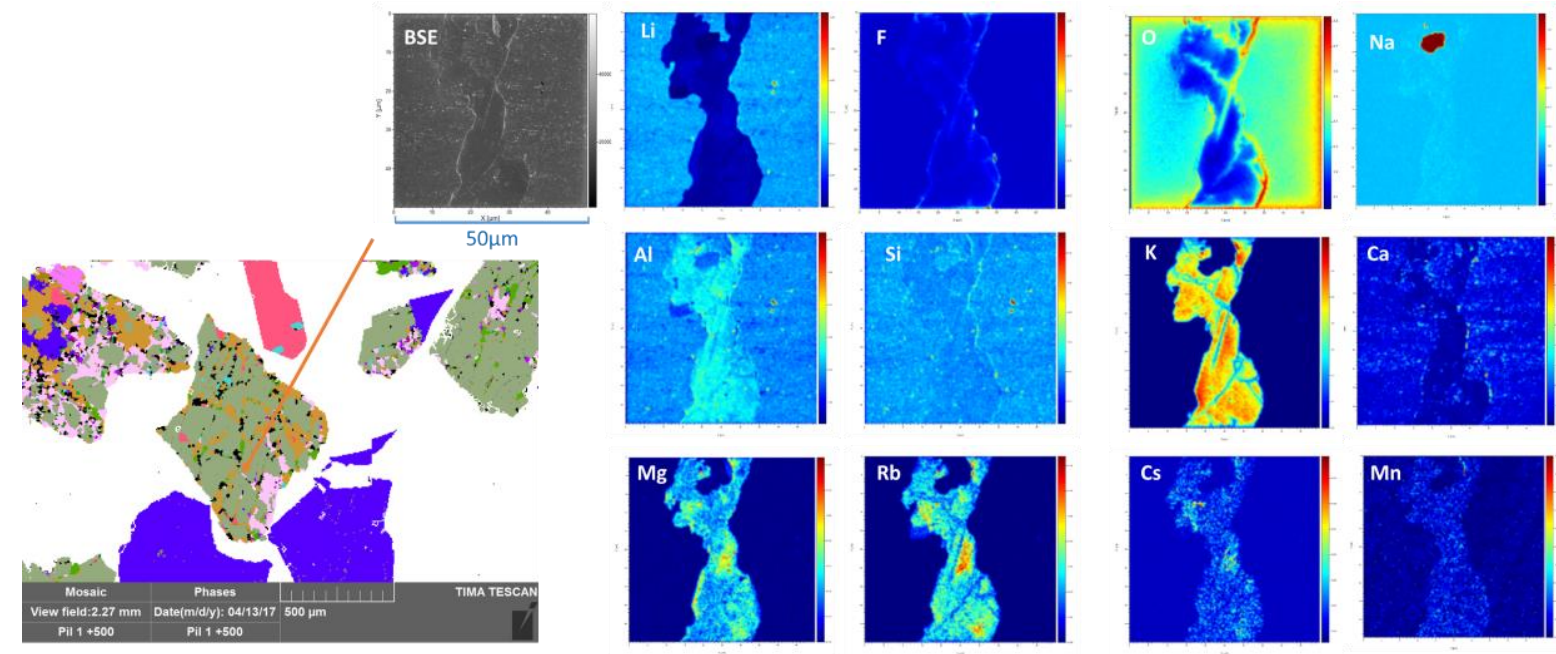

Figure 7: Mineral composition and elemental distribution maps from ToF-SIM analysis for Pilgangoora Pil1 sample showing element distributions associated with lepidolite (brown) and spodumene (Olive green). Other minerals present are calcite (Light pink), quartz (Blue), feldspar (reddish pink) and muscovite (darker pink).

\subsection{Lithium deportment}

The Li deportment was calculated by evaluating the laser ablation data and relating the measured $\mathrm{Li}$ concentrations in discrete Li-containing minerals to the TIMA modal abundance of the minerals in the sample. Figure 8 shows that the majority of $\mathrm{Li}$ is associated with spodumene particles, and notable amounts of lepidolite, trilithionite and polylithionite in Pill and less in the other samples. 


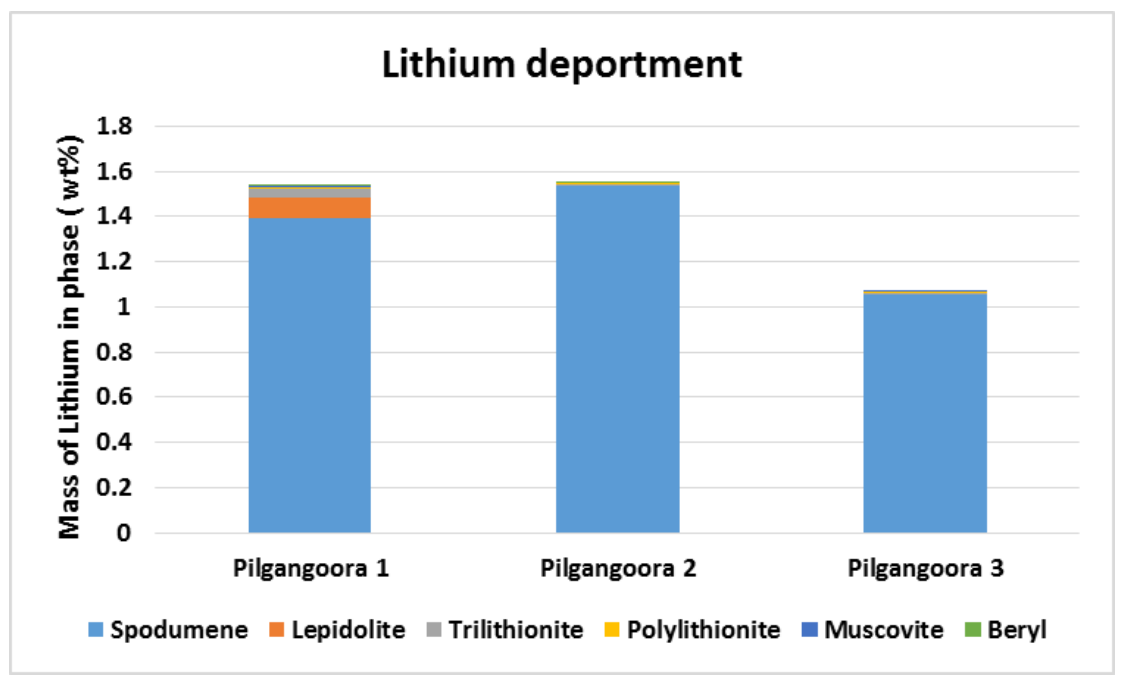

Figure 8: The distribution of lithium in Pilgangoora pegmatite minerals.

\section{$4 \quad$ Mineral processing considerations}

\subsection{Mineral locking and liberation characteristics of spodumene}

Figure 9 shows the locking and liberation characteristics of spodumene in all three samples. The level of locking is expressed as a function of the surface area of a particular mineral which may be exposed to a leach solution. Mineral liberation expresses how much (or degree) of a mineral of interest is liberated from other minerals. In this study the liberation classes were classified based on the surface area of spodumene as liberated $(\geq 90 \%)$, mostly liberated $(<90 \%, \geq 70 \%)$, middling $(<70 \%, \geq 30 \%)$ or locked $(<30 \%)$.

At a $\mathrm{P}_{100}$ of $4 \mathrm{~mm}$ between 70 to $90 \%$ of spodumene grains in all three samples have free, liberated surfaces not in contact with other minerals (Figure 9 a,c,e) and would make them accessible to a flotation reagents for concentrating. The graphs in Figure 9 illustrate that most of the spodumene particles reside in the coarse fractions. Around 30\% of spodumene grains in Pill are in contact with Li bearing micas, muscovite, calcite, feldspars and quartz (Figure 9a), whereas in Pil2 and Pil3 samples around $10 \%$ of the spodumene grains are contact with quartz, muscovite and feldspars (Figure 9c \& e).

While the Pill sample has spodumene particles with high surface exposure (70\%) as evaluated from the locking assessment, liberation analysis of particles indicate a high proportion of the particles representing $47 \%$ of the spodumene fall into the middling class and $10 \%$ of particles fall into the locked class (Figure 9b). The liberated and mostly liberated classes makeup 10\% and 34\% of spodumene particles respectively. The locked spodumene particles have mineral compositions consisting of $4 \mathrm{wt} \%$ spodumene associated mainly with quartz (57 wt \%) and moderate amounts of feldspars (21 wt \%) and micas (13 wt \%). The spodumene particles in the middling class are made up of $70 \mathrm{wt} \%$ spodumene containing micas (12 wt \%), calcite (7 wt \%) and feldspars (3 wt \%). The mostly liberated and liberated class in Pil1 are predominately spodumene (92 \& $98 \mathrm{wt} \%$ respectively) with minor amounts of calcite, micas, quartz and feldspars in the mostly liberated class and trace amounts in the liberated particles class. The majority of micas in the middling class are made up of lithium bearing micas of lepidolite composition and trilithionite. Muscovite, the lithium poor mica, is mainly present in the locked class. To liberate the spodumene in the middling class would require further particle size reduction to reject the mica, quartz and feldspar.

Pil 2 and 3 samples have spodumene with high surface exposure (83-84\%) that are slightly greater than the Pil1 sample (Figure 9c \&e). In the Pil2 sample the majority of spodumene is classified into the mostly liberated (43\%) and liberated (37\%) classes (Figure 9d). The Pil3 sample has a slightly less spodumene classified in the mostly liberated (22\%) class and a higher content classified in the 
liberated (47\%) class than the Pil2 sample (Figure 9f). The spodumene associated with the locked (4$5 \%)$ and middling (15-26\%) classes in both Pil2 and Pil3 samples are much less than the Pill sample.

The spodumene particles in the locked class in Pil 2 consists of low abundance of spodumene at 3 $\mathrm{wt} \%$, associated mainly with quartz (59 wt\%) and moderated amounts of feldspars (29 wt \%). The spodumene particles in the middling class have a high spodumene content of $65 \mathrm{wt} \%$ and contain moderate quartz (11 wt \%) and feldspars (14 wt \%) contents and a minor muscovite (4 wt\%) content. The mostly liberated class is rich in spodumene at $94 \mathrm{wt} \%$ and contains minor concentrations of feldspar ( $2 \mathrm{wt} \%)$, quartz ( $1 \mathrm{wt} \%)$ and muscovite $(2 \mathrm{wt} \%)$, whereas the liberated class consists of 98 wt $\%$ spodumene with trace amounts of quartz, feldspar and muscovite.

The Pil3 sample has similar mineral composition in the locked class to the Pil2 sample with $1 \mathrm{wt} \%$ of spodumene and high content of quartz (53 wt $\%$ ) and feldspar (41 wt $\%$ ) and minor muscovite (4 wt $\%$ ) content. The middling class of the Pil3 sample contains high spodumene content of $61 \mathrm{wt} \%$, moderate amounts of quartz (12 wt \%) and feldspar (18 wt \%) and minor muscovite (4 wt \%) content. The mostly liberated and liberated classes are predominately spodumene at $93 \mathrm{wt} \%$ and $98 \mathrm{wt} \%$ respectively, with minor amounts of quartz and feldspars in the mostly liberated class and trace amounts in the liberated particle class.

Overall, the high spodumene content in the middling samples would favour further liberation, especially for the Pill type sample where a higher content of spodumene rich particles are associated with other minerals. The liberated samples are mainly concentrated spodumene, whereas the spodumene lost in the locked classes is small.

\subsection{Grade-recovery of spodumene}

Figure 10 shows the theoretical grade-recovery curves determined from the liberation characteristics for spodumene at different grind sizes for all three samples.

The theoretical grade-recovery curve for an ore is defined as the maximum expected recovery that can be achieved by physical separation of a mineral at a given grade (McIvor \& Finch, 1991). This is determined by the surface area liberation of the mineral of interest and is directly related to the grind size. Theoretical grade-recovery curves provided by automated mineralogy techniques are generated from 2D liberation measurements and therefore overestimate the true liberation by a certain amount and therefore only provide a guide. Test work is always required to validate the results.

The modal mineralogical distribution of spodumene within each size fraction is represented on the curve as the grade value at $100 \%$ recovery. The proportion of fully liberated spodumene particles, based on the exposed surface area, is represented on the curve as the recovery value achieved at $100 \%$ spodumene grade. The further the whole curve is to the right in the graphs, the better the expected grade and recovery of spodumene.

Overall, high grade recovery yields in the high $90 \%$ can be expected for all three samples. At $90 \%$ spodumene recovery the lithium grade is upgraded from $1.5 \mathrm{wt} \%$ to $3.0 \mathrm{wt} \%\left(6.5 \mathrm{wt} \% \mathrm{Li}_{2} \mathrm{O}\right)$ in the Pill sample, from $1.5 \mathrm{wt} \%$ to $3.4 \mathrm{wt} \%\left(7.3 \mathrm{wt} \% \mathrm{Li}_{2} \mathrm{O}\right)$ in the Pil2 and from $0.99 \mathrm{wt} \%$ to $3.2 \mathrm{wt} \%$ (6.9 wt $\left.\% \mathrm{Li}_{2} \mathrm{O}\right)$ in the Pil3 sample. Improvements in the recovery of spodumene in the coarse fractions could be considered by further particle size reduction to liberate spodumene in the middling class described above.

To liberate spodumene grains associated with lepidolite and calcite grains in the middlings class in Pill sample would require a finer grind size of $+125 \mu \mathrm{m}$. Grinding the Pill to $+125 \mu \mathrm{m}$ at $90 \%$ spodumene recovery would increase lithium grade to $3.15\left(6.8 \mathrm{wt} \% \mathrm{Li}_{2} \mathrm{O}\right)$. Optimum grind size for the Pil2 sample is $+1400 \mu \mathrm{m}$ and there appears to be no benefit in further size reduction. In the Pil3 sample a $+500 \mu \mathrm{m}$ is favourable, but a slight improvement to breakdown spodumene, feldspar and quartz intergrowths may be expected in a grind size range of 125 to $75 \mu \mathrm{m}$. Grinding Pil3 to $+500 \mu \mathrm{m}$ favours increased spodumene recovery to $95 \%$ at a grade of $3.5 \mathrm{wt} \%\left(7.5 \mathrm{wt} \% \mathrm{Li}_{2} \mathrm{O}\right)$. 

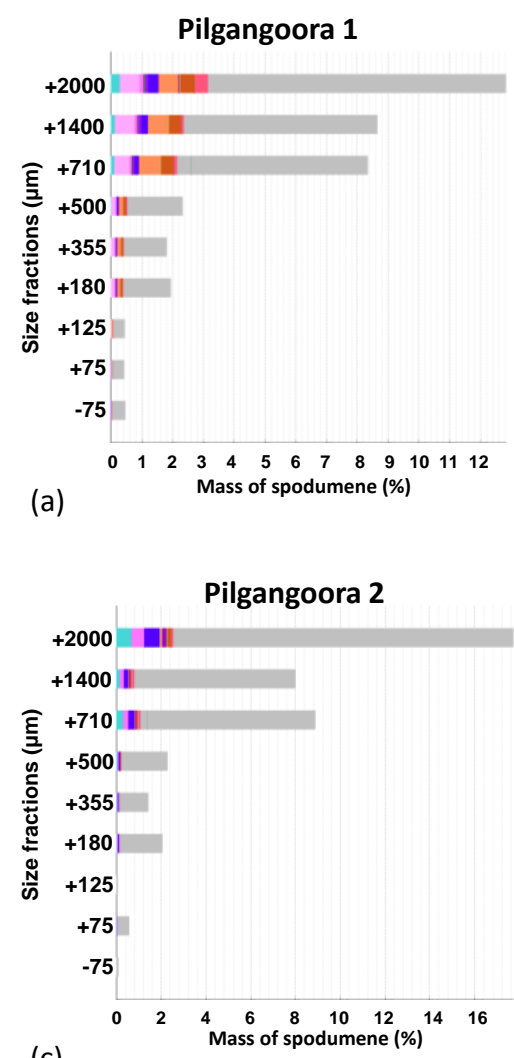

(c)

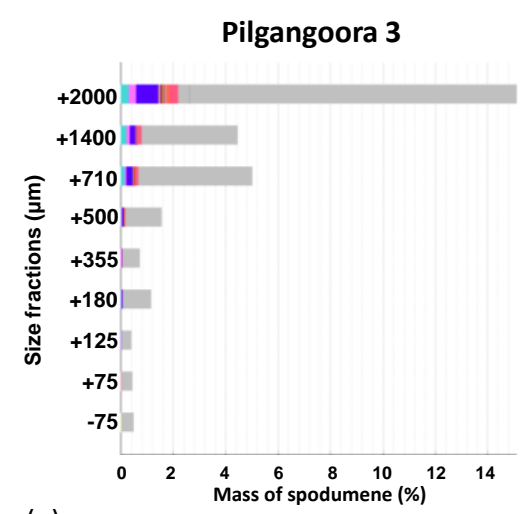

(e)

Figure 9: Mineral locking (a,c,e) and liberation characteristics (b,d,f) for spodumene in the three samples for each size fraction. Mass of spodumene is related to the percentage in the whole sample and liberation is based on surface area of spodumene particles (Liberated $\geq 90 \%$; Mostly liberated $<90 \% \geq 70 \%$; Middling $<70 \% \geq 30 \%$; Locked $<30 \%$ ).
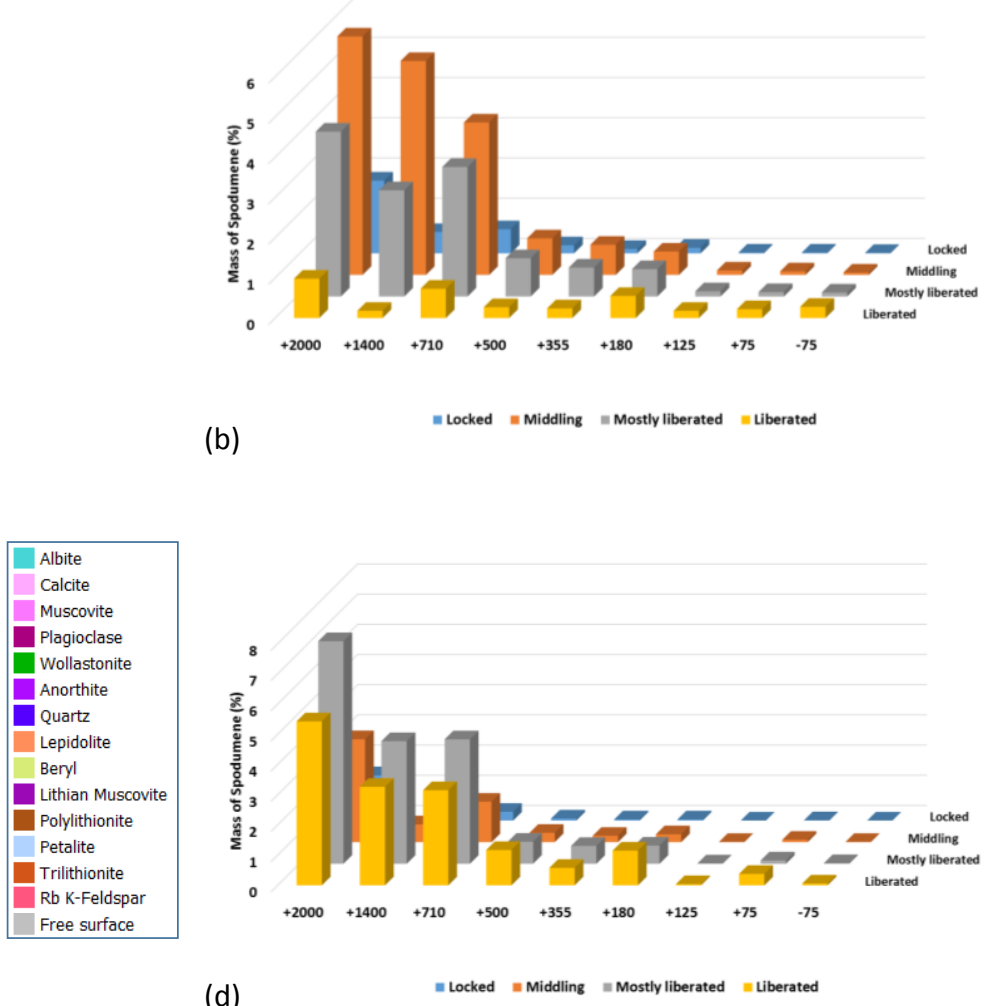

(d)

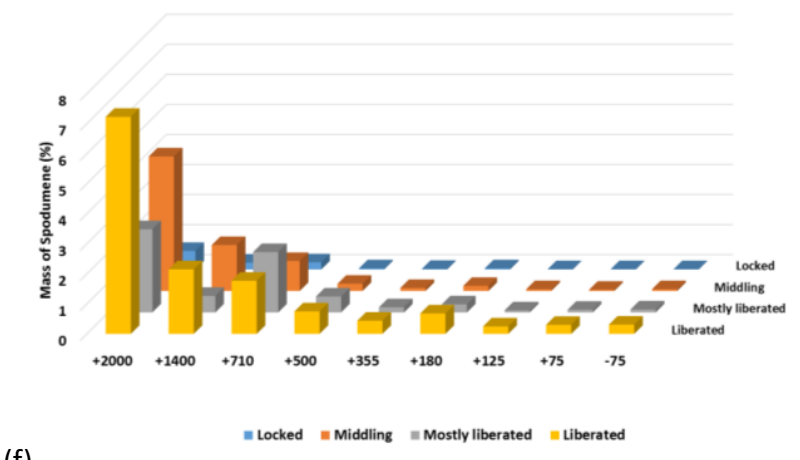

(f) 
Minerals Engineering

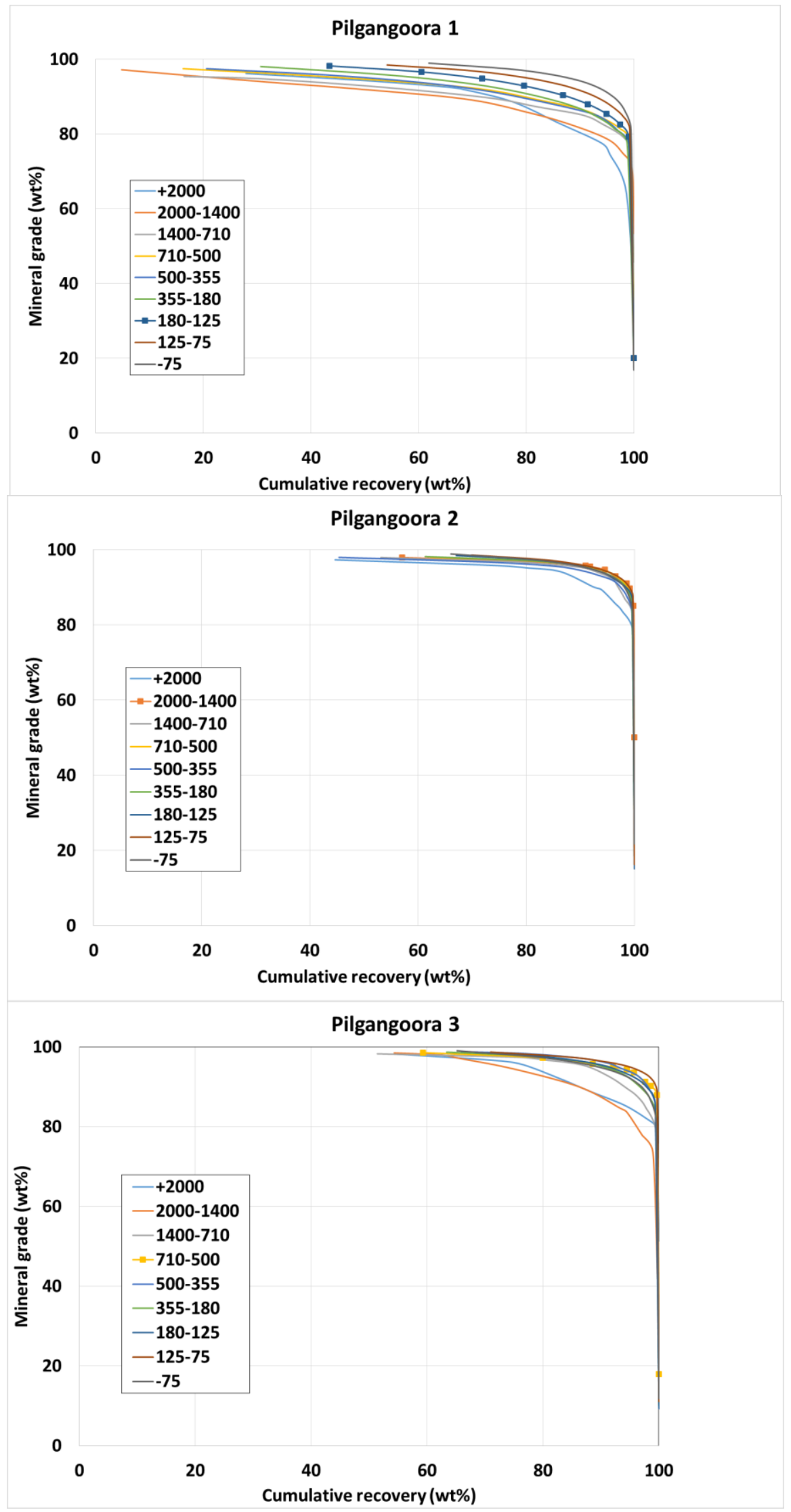

Figure 10: Theoretical grade-recovery curves for recovering spodumene for all three samples. High grade recoveries are possible at coarse grind size as illustrated for data with square markers. 


\subsection{Assessment of other valued minerals}

In addition to lithium, LCT complex spodumene pegmatites can contain valuable $\mathrm{Ta}, \mathrm{Nb}$ and $\mathrm{Sn}$ contents which can also be economical to recover. While the bulk concentration observed in chemical assays are not high, most of the $\mathrm{Ta}, \mathrm{Nb}$ and $\mathrm{Sn}$ minerals identified in samples, were fairly well liberated (Figure 11) and can be separated and concentrated by heavy mineral separation techniques. Cassiterite make up between 0.01 and $0.03 \mathrm{wt} \%$ of samples with 33\% grains free with the rest associated with spodumene grains. Tantalite makes up only $0.05 \mathrm{wt} \%$ of the Pill sample, whereas it is only $0.02 \mathrm{wt} \%$ and $0.03 \mathrm{wt} \%$ in the Pil 2 and Pil3 sample respectively. However, the tantalite grains appear largely free of other minerals. Beryl is a source of both Be and Cs in these samples and can also be concentrated. The beryl is mostly in the Pill sample at $0.86 \mathrm{wt} \%$ with $70 \%$ of grain surfaces exposed. The coarser beryl grains would require further grinding to remove the fine lepidolite and feldspar veinlet structures observed within beryl grains.

Rubidium is associated with lepidolite, trilithionite and the feldspar mineral rubicline. The high content of $\mathrm{Rb}(1 \mathrm{wt} \%)$ and abundance of free grains would make the $\mathrm{K}$ feldspar a source of rubidium, particularly in the Pil3 sample (K- feldspar content $21 \mathrm{wt} \%$ ). Rubicline particles observed in polished mounts contained high surface exposure at 53\% in Pil1, 68\% in Pil2 and 80\% in Pil3. In the Pill sample $9 \%$ to $15 \%$ of the rubicline surfaces are associated with albite, quartz and micas and spodumene. In Pil 2 and 3 samples $10 \%$ of the rubicline surfaces are associated with albite. The quartz, mica and spodumene associations are much lower in the Pil3 sample at between 2 and 3\%, whereas in Pil2 it is slightly higher at $8 \%$ of the surface. Theoretical grade recovery curves indicated that $95 \%$ of the rubicline can be recovered at a grade of $85 \%$ in Pil3, whereas $80 \%$ can be recovered at a grade of $75 \%$ for Pil 2 and $70 \%$ recovered at a grade of $60 \%$ in Pill, if no further grinding to liberate grains is carried out.

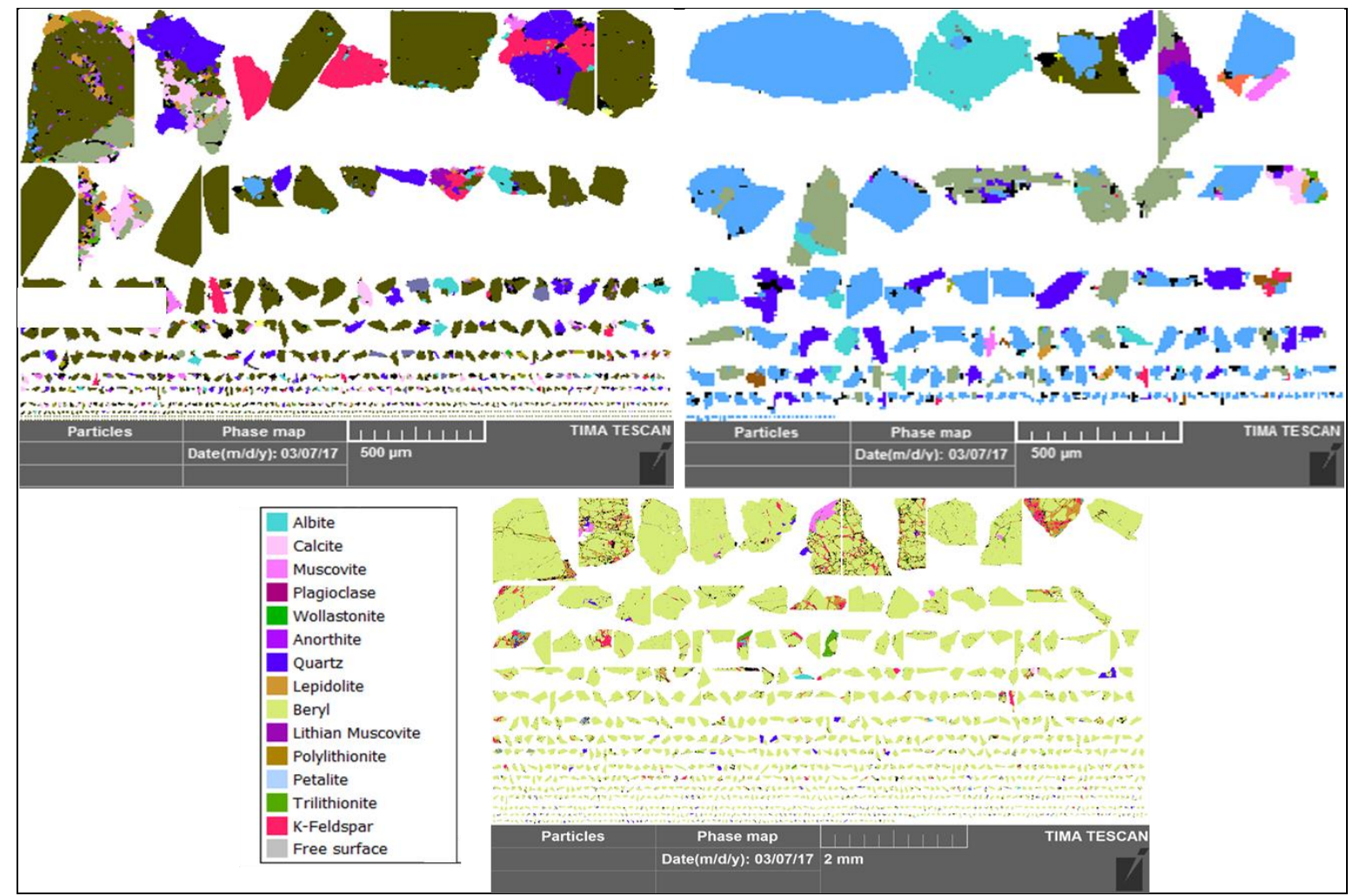

Figure 11: Line-up of grains of tantalite (olive green), cassiterite (blue) and beryl (light green) grains present in all three samples.

\subsection{Process considerations in treating spodumene ores}

High grade spodumene concentrate is normally produced through a series of beneficiation operations, including gravity, heavy media, magnetic and flotation separation processes prior to pyrometallurgical and hydrometallurgical industrial processing of spodumene for the extraction of lithium. The chemical 
extraction of lithium from spodumene concentrate normally requires the phase transformation from monoclinic $\alpha$-form to tetragonal $\beta$-form at elevated high temperatures $\left(800\right.$ to $\left.1500^{\circ} \mathrm{C}\right)$ to volumetrically expand the spodumene structure and allow reagents to penetrate the mineral structure (Salakjani, et al., 2016). A number of reagents such as chloride, fluorine, carbonate, sulfate or sulphuric acid media have been used and tested for the extraction of lithium and involve either direct addition of the reagent to a roasting process or processing in an autoclave (Choubey et al., 2016). Lithium is then recovered by precipitation, resin or solvent extraction approaches.

Based on mineralogical observations in the current study, the majority of the main gangue minerals, quartz, feldspar and albite can be rejected at a coarse grind size $(-4 \mathrm{~mm}$ in this study) to upgrade the spodumene and Li content. The iron content (81-1475ppm) in the spodumene is low and therefore make these spodumene concentrates suitable for use in ceramic and glass applications.

The upgrade of spodumene can be achieved by either or a combination of dense media separation and flotation techniques commonly used in the industry (Gibson et al., 2017). The coarse nature of liberated spodumene particles and differences in specific gravities between spodumene and feldspars, micas and quartz minerals allow dense media separation approach to be used. The predicted upgrade of spodumene concentrate to around $6.0 \mathrm{wt} \mathrm{L}_{2} \mathrm{O}$ in this study is consistent with expected grades in the concentrator being built at Pilgangoora (Pilbara Minerals Ltd, 2017).

Upgrading of spodumene particles further which contain veinlets of calcite and lepidolite grains or feldspar and quartz, observed in the middling classes, would require further grinding to liberate. However, the effect of the presence of these mineral impurities in the spodumene in downstream processing will be dependent on the method of processing. The Pill sample contains around $2.6 \mathrm{wt} \%$ calcite which will be consumed in any acidic process $\left(\sim 25.6 \mathrm{~kg} / \mathrm{t}_{\text {ore }}\right.$ of sulphuric acid).

For roasting processes using acidic conditions (e.g. sulphuric acid) minerals containing F (i.e. lepidolite, muscovite) have to be managed or removed to prevent hydrofluoric (HF) emissions. Calcium carbonate or lime have been used as additives to the roast to capture and remove $\mathrm{F}$ and so in this case the presence of calcite in the Pill may help facilitate fixing of some of the fluorine. The presence of feldspar as found in Pil2 and Pil3 samples needs to be minimised, otherwise the temperature of roasting has to be controlled to below the melting point of feldspars. Studies reported by Peltosaari et al (2017) observed particle agglomeration in spodumene concentrates from the partial melting of gangue-based alkali-feldspar at temperatures above $1025^{\circ} \mathrm{C}$, which can lead to a decrease in lithium recovery during the extraction process.

An alternative approach is the halogen based Sileach ${ }^{\mathrm{TM}}$ process which is a less energy intensive atmospheric leach process that uses the addition of ground fluoride minerals followed by sulphuric acid to process slurry to generate $\mathrm{F}^{-}$in solution and preferentially react with the silicates without any accumulation of HF in the slurry (Griffin 2017). Hence, the presence of fluorine minerals such as lepidolite in Pill can be conditioned and used to decompose Li- bearing siliceous minerals. Lithium Australia NL has recently tested Pilgangoora ore using their atmospheric halogen based Sileach ${ }^{\mathrm{TM}}$ process, but details have not been published (Lithium-au.com 2016).

The high concentration of $\mathrm{Rb}(0.9-3.6 \mathrm{wt} \%)$ and $\mathrm{Cs}(0.1-0.8 \mathrm{wt} \%)$ in feldspar and beryl respectively make them a favourable resource for these elements and ultimately need to be recovered separately along with Li. Feldspars can be floated by reverse floatation method from the spodumene float quartz tails by conditioning the slurry with hydrofluoric acid and adjusting the $\mathrm{pH}$ to $2-2.5$, adding tallow amine acetate collector, kerosene and a frother (Redeker, 1981; Heyes et al. 2012). Further upgrade of $\mathrm{Rb}$ feldspar from albite is by the addition of $\mathrm{NaCl}$ during flotation.

In addition, both $\mathrm{Ta}$ and $\mathrm{Sn}$ minerals are liberated and can be concentrated by processes such as gravity separation (Bale and May, 1989).

\section{Conclusions}

A combination of analytical microscopy and mass spectrometry techniques were used to characterise a sample from the Pilgangoora pegmatite deposit in Western Australia, Australia. The sample was first split into three different lithologies (Pil1, Pil2, Pil3) based on colour and texture. The samples 
were crushed and then subjected to electrodynamic fragmentation procedure and screened to pass $4 \mathrm{~mm}$ separately. The electrodynamic fragmentation approach preserves the original physical and textural features, and allows the study of minerals in their nature form which is often sacrificed during grinding and milling. XRPD and TIMA analysis indicated that all samples are made up of predominately spodumene, quartz and feldspars. Cross section analysis of the Pill particles show some spodumene particles contain micaceous minerals and calcite, whereas Pil2 and Pil3 have spodumene associated with feldspars and quartz. The majority of Li measured by LA-ICPMS and ToF-SIMS is associated with spodumene and in small quantities in the Li bearing micas lepidolite, trilithionite and polylithionite and in trace amounts of beryl.

Based on mineralogical observations and TIMA analysis the majority of the main gangue minerals, quartz, feldspar and albite can be rejected at a coarse grind size (-4mm in this study), to recover $90 \%$ of the spodumene with $\mathrm{Li}$ upgrade from 0.99-1.5 wt\% $\mathrm{Li}$ to 3.0-3.5 wt\% (6.5-7.5 $\mathrm{Li}_{2} \mathrm{O}$ ). The iron content (81-1475 ppm) in the spodumene is low and therefore make these spodumene concentrates suitable for use in ceramic and glass applications.

Improvements in the recovery of spodumene in the coarse fractions could be considered by further particle size reduction to liberate spodumene from micas, quartz and feldspars in the middling class particles which account for between 15 and $49 \%$ of the sample. The effect of the presence of mica and feldspar mineral impurities within the spodumene in downstream processing will be dependent on the method of processing. The use of atmospheric leach approach such as the Sileach process can eliminate the concern of micas containing fluorine or feldspars in conventional roasting processes.

The high concentration of $\mathrm{Rb}(0.9-3.6 \mathrm{wt} \%)$ and $\mathrm{Cs}(0.1-0.8 \mathrm{wt} \%)$ in feldspar and beryl respectively make them a favourable resource for these elements and ultimately need to be recovered separately along with lithium from spodumene.

$\mathrm{Ta}, \mathrm{Be}, \mathrm{Nb}$ and $\mathrm{Sn}$ minerals identified in samples, were fairly well liberated and can be separated and concentrated by heavy mineral separation techniques.

\section{Acknowledgements}

Permission to publish by Lithium Australia NL is acknowledged. This study was supported by Lithium Australia NL. The Tescan Integrated Mineral Analysis (TIMA) instrument was funded by a grant from the Australian Research Council (LE140100150) and is operated by the John de Laeter Centre at Curtin University with the support of the Geological Survey of Western Australia, University of Western Australia and Murdoch University. The use of the Tescan Lyra was supported by the Science and Industry Endowment Fund (SIEF).

\section{$7 \quad$ References}

AIG (2016) Australian insitiute of geoscientists, https://www.aig.org.au/librar/seminarpresentations/wa-branch-presentations/\#lithiumgraphiteaug16.

Aylmore M G., Merigot, K., Quadir, Z., Rickard, W. D.A., Evans N. J., McDonald, B. J., Catovic, E., Spitalny, P. (2017) Applications of advanced analytical and mass spectrometry techniques to the characterisation of micaceous lithium-bearing ores., Minerals Engineering (in press).

Alberts, D., von Werra, L., Oestlund, F., Rohner, U., Hohl, M., Michler J. \& Whitby, J. A. (2014) Design and performance of two orthogonal extraction time-of-flight secondary ion mass spectrometers for focused ion beam instruments Instrumentation Science \& Technology, 42(4), 432-445.

Alex, P., Suri, A.K., 1996. Processing of low grade zinnwaldite (lithium-mica) concentrate. Light Metals, 1165-1168.

Bale, M. D. \& May, A. V. (1989) Processing of ores to produce tantalum and lithium minerals Engineering 2(3), 299-320.

Brandt, F. \& Haus, R., (2010): New concepts for lithium minerals processing. Minerals Engineering 23, 659-661. 
Cameron M., Sueno, S., Prewitt, C. T., Papike, J. J., (1973) High-Temperature crystal chemistry of Acmite, Diopside, Hedenbergite, Jadeite, Spodumene and Ureyite, American Mineralogist, 58, 594-618.

Cerny, P.\& Ferguson, R.B. (1972): The Tanco Pegmatite at Bernic Lake, Manitoba. IV. Petalite and spodumene relations. Canadian Mineralogist. 11, 660-678.

Cerny, P. \& Ercit, T.S. (2005) The classification of granitic pegmatites revisited. Canadian Mineralogist, 43, 2005-2006.

Charoy, B., Lhote F., Dusausoy, Y. (1992) The crystal chemistry of spodumene in some granitic aplite-pegmatite of Northern Portugal, Canadian Mineralogist 30,.639-65

Chernet, T. (2010) High voltage selective fragmentation for detailed mineralogical and analytical information, Case study: Oiva's gold-quartz-dyke, in the Lapland granulite belt, Laanila, Northern Finland. Process Mineralogy, p. 2010.

Chen, Y., Tian, Q., Chen, B., Shi, X., Liao, T., 2011. Preparation of lithium carbonate from spodumene by a sodium carbonate autoclave process. Hydrometallurgy 109 (1), 43-46.

Choubey, P. K., Kim, M., Srivastava, R. R., Lee, J-C \& Lee, J-Y., (2016) Advance review on the exploitation of the prominent energy-storage element: Lithium. Part I: From mineral and brine resources. Minerals Engineering 89, 119-137.

Deer, W.A., Howie, R.A. \& Zussman, J. (1978): Rock-Forming Minerals, 2A. Single-Chain Silicates. Longman, London.

Distin, P.A., Phillips, C.V., (1982) The acid extraction of lithium from the granites of South West England. Hydrometallurgy 9, 1-13.

Dresler, W., Jena, B.C., Reilly, I.G., Laffin, S., Egab, E., (1998) The extraction of lithium carbonate from a pegmatite. In: Welch, B. (Ed.), Light Metals. TMS, Warrendale, PA, pp. 1303-1308.

Garrett, D.E., 2004. Handbook of Lithium and Natural Calcium Chloride: Their Deposits, Processing, Uses and Properties. Academic Press.

Gasperin, M. (1971): Structure cristalline de RbAlSi3O8. Acta Crystallography B27, 854-855.

Griffin, A. (2017) Hydrometallurgical processes for the recovery of lithium from silicates. Proceeding of ALTA 2017, 20-27 May, Perth, Australia.

Gibson, C., Aghamirian, M, and Grammatikopoulos, T., (2017) The beneficiation of lithium minerals from hard rock deposits. Mining Engineering, 69(8), pp. 8.

Grammatikopoulos, T.A., Pearse, G., Gelcich, S., and Gunning, C. 2009. Quantitative characterization of spodumene ore by automated mineralogy from the Moblan rare Metals pegmatite Deposit, Quebec, Canada. Proceedings of the 48th Annual Conference of Metallurgists of CIM (MetSoc), pp 65-76.

Heyes, G W Allan, G C Bruckard W J \& Sparrow G J (2012) Review of flotation of feldspar, Mineral Processing and Extractive Metallurgy, 121(2), 72-78.

Kyono, A., Kimata. M. (2001) Refinement of the crystal structure of a synthetic non-stoichiometric Rb-feldspar Mineralogical Magazine, 65, 523-531.

Lastra, R., Cabri, L.J., (2003) Comparative liberation study by image analysis of Merensky reef samples comminuted by electric-pulse disaggregation and by conventional crusher. In: Lorenzen, L., et al. (Eds.), Proceedings of the XXII International Mineral Processing Congress, vol. 1. pp. 251-260.

Lithium-Au.com (2016) http://lithium-au.com/wp-content/uploads/2013/09/0292017-ANSTO-PilotResults-Run-1A.pdf.

London D. \& Burt, D. M. (1982) Lithium aluminosilicate occurrence in pegmatites and the lithiumaluminosilicate phase diagram. American. Mineralogy,.67,483-493.

Meshram, P., Pandey, B.D. \& Mankhand, T.R., (2014): Extraction of lithium from primary and secondary sources by pre-treatment, leaching and separation: a comprehensive review. Hydrometallurgy 150, 192-208.

McIvor R. E., Finch, J.A. (1991) A guie to interfacing of plant grinding and flotation operations, Minerals Engineering, 4(1), 9-23.

Olivier, C.A., Nenniger, E.H., 1979. Continuous process for the production of lithium carbonate. CIM Bull. 72 (807), 131-136. 
Peltosaari, O., Strand, S., Tanskanen, P., Heikkinen, E., Sirén O., \& Lamberg P. (2017) Mineralogical study to determine agglomeration free heat treatment conditions for spodumene concentrate. Proceedings of the Process Mineralogy '17 Conference, Cape Town, South Africa, $15 \mathrm{pp}$.

Pilbara Minerals Ltd (2017) The world's leading lithium development project, Diggers and Dealers presentation, August 2017.

Sandmann, D. \& Gutzmer, J. (2013) Use of Mineral Liberation Analysis (MLA) in the characterisation of Lithum-bearing micas, Journal of Minerals and Materials Characterization and Engineering, 1, 285-292.

Salakjani, N. K. Singh, P., Nikoloski, A. N. (2016) Mineralogical transformations of spodumene concentrate from Greenbushes, Western Australia. Part 1: Conventional heating, Minerals Engineering 98, 71-79.

Teertstra D. K. ,Cerny P., \& Hawthorne F. (1998) Rubidium feldspars in granitic pegmatites, The Canadian Mineralogist 36, pp. 483-496.

Wang, E., Shi, F., Manlapig, E., (2012) Mineral liberation by high voltage pulses and conventional comminution with same specific energy levels. Minerals Engineering 27-28, 28-36.

Whitby, J. A., Östlund, F., Horvath, P., Gabureac, M., Riesterer, J. L., Utke, I., Hohl, M., Sedláček, L. Jiruše, J. Friedli, V., Bechelany, M. \& Michler, J., (2012) High Spatial Resolution Time-ofFlight Secondary Ion Mass Spectrometry for the Masses: A Novel Orthogonal ToF FIB-SIMS Instrument with In Situ AFM, Advances in Materials Science and Engineering, 13pp. 